\title{
Determination of Quality Criteria of Urban Pedestrian Spaces
}

\author{
Fatma Aşilioğlu ${ }^{1} \mid$ Rukiye Duygu Çay ${ }^{2}$
}

Received: 2020-05-01 | in its final version: 2020-08-19

\begin{abstract}
Pedestrian spaces are important public spaces that promote, support, and improve urban public life. Generally, these spaces are created by pedestrianizing existing streets, squares, plazas, and so forth as part of overall planning. Today, such an approach is considered an important urban strategy. One of the aims of pedestrianization is to clear certain areas from vehicular traffic in order to transform them into unconstrained and safe environments. Another purpose of pedestrianization is to improve mixed-use areas to ensure better performance of their functions. This study aims to determine the quality criteria that one should take into account while creating and managing pedestrian spaces and to measure the quality level of downtown Ankara's oldest and most used nine streets. For this purpose, a two-stage questionnaire, consisting of 22 questions, was conducted. The questions were collected from related literature and similar research. The data obtained in the first stage were evaluated by factor analysis, which is a quantitative method. The findings showed that the quality criteria were grouped into five main factors: design, maintenance, activities, accessibility, and safety. The data obtained in the second stage revealed the extent that the streets in the study area met these criteria. The study's findings revealed that the streets with the highest quality level were izmir and Yüksel streets, and the street with the lowest quality level was Bayındır Street. The research determined the pedestrian space quality criteria in general and the strengths and weaknesses of the study area in particular. The results are a guide for planners, designers, managers, and policymakers who are engaged in developing existing spaces and creating new ones.
\end{abstract}

Keywords: Public space; pedestrianization; factor analysis; pedestrian design

Citation

Aşilioğlu, F. \& Duygu Çay, R. (2020). Determination of Quality Criteria of Urban Pedestrian Spaces. ACE: Architecture, City and Environment, 15(44), 9297. DOI http://dx.doi.org/10.5821/ace.15.44.9297

1 Dr. Landscape Architect, Ankara University Kalecik Vocational School, Landscape and Ornamental Plants Program (ORCID: 0000-0001-9869-9638), ${ }^{2}$ Dr. Landscape Architect, Assistant professor, Trakya University Faculty of Architecture, Department of Landscape Architecture (ORCID: 0000-0001-9359-4028). Contact email: fatma.asilioglu@ankara.edu.tr

ACE, 15 (44.) CC BY-ND 3.0 ES | UPC Barcelona, España | Determination of Quality Criteria of Urban Pedestrian Spaces. DOI: http://dx.doi.org/10.5821/ace.15.44.9297 


\section{Introduction}

Even though there are various definitions of public spaces based on ownership, control, access, and use, they are, in the most basic sense, areas where users are subject to certain rules, creating social uses and behavior (Mehta, 2014). Today, there is a growing interest in revitalizing mixed-use places and improving the infrastructure of these areas, especially in urban centers. Even individuals who do not appreciate urban life avail the use of such spaces due to work or the availability of certain amenities as well as to enjoy activities like shopping, entertainment, and socialization (Mehta \& Bosson, 2018). Urban research shows that parks, plazas, squares, and other public spaces have the capability to facilitate, support, and develop public life, and they form an important part of it.

In particular, streets are a symbol of the public space and are representative of the outer space (Jacobs, 1993). Streets are essential for people to participate in social, cultural, and economic activities and to engage in leisure activities (Mehta, 2007). As a result, some streets are heavily used by pedestrians and vehicles for various purposes (Bayraktar, Aslanboğa, Özkan, Güney, \& Türkyılmaz, 1987; Monheim, 2003; Sayyadi \& Awasthi, 2012; Yalçınkaya, 2007).

Because these streets are centrally located and meet commercial, social, cultural, and recreational requirements all at the same time, the number of users gradually increases, which makes the coexistence of pedestrians and vehicular traffic impossible. In urban areas where vehicular traffic can be solved by alternative roads, dedicating all or parts of such roads to pedestrians has been regarded as a common solution globally. This process, which is called pedestrianization, is the allocation of urban roads that are deemed necessary to pedestrians on a full-time or part-time basis (Kaplan \& Acuner, 2005; Sayyadi \& Awasthi, 2012). Pedestrianization aims to offer comfortable and secure spaces (Bayraktar et al., 1987; Maliene \& Diciunaite-Rauktiene, 2015; Sayyadi \& Awasthi, 2012) by separating pedestrian and vehicular movements (Korça \& Türkoğlu, 1991). It is a tool that serves three purposes, namely, urban economy, urban quality, and social welfare (Yalçınkaya, 2007). Pedestrianization has become a part of urban design in major urban centers (Korça \& Türkoğlu, 1991) and pedestrian spaces are undoubtedly important public spaces of urban centers (Tudor-Locke, Bittman, Merom, \& Bauman, 2005). Urban public spaces are sites of collective memories and offer an understanding of people's feelings about the cities' spiritual charm (Mehan, 2016). Because they act as a place of interaction between people and the environment (Cattell, Dines, Gesler, \& Curtis, 2008; Nasution \& Zahrah, 2012) urban public spaces positively affect the quality of urban life (Das, 2008; Mehan, 2016). Many studies show that urban public spaces influence harmony, social interaction (Cohen, Inagami, \& Finch, 2008; Gehl, 2011; Hajmirsadeghi, Shamsuddin, Lamit, \& Foroughi, 2013; Mehan, 2016; Stauskis, 2018), and physical and mental health (Chiesura, 2004; Hansmann, Hug, \& Seeland, 2007; Pacione, 2003; Stauskis, 2018; Tudor-Locke et al., 2005) of people.

Today, pedestrian spaces are created in line with pedestrian experiences (Kuntay, 1994; Maliene \& Diciunaite-Rauktiene, 2015; Surat \& Yaman, 2015) and experimental strategies provide more flexible, adaptable, and dynamic urbanism approaches (Bishop \& Williams, 2012). Experimental projects are based on people's participation in urban transformations (Project for Public Spaces, 2008), they are part of the participatory planning and are directly related to the needs of society (Rossini, 2019). There are many instances in the world where pedestrians share their ideas, and temporary projects are created by adopting those ideas to revive and activate certain public spaces (Rossini, 2019). These temporary actions allow urban designers and planners to rehearse before they make permanent interventions (Lydon \& Garcia, 2015; Weiss, 2007). The urban environment is a participation area and requires systems that are compatible with the ideas and needs of those living in the area (Rossini, 2019).

ACE, 15 (44.) CC BY-ND 3.0 ES | UPC Barcelona, España | Determination of Quality Criteria of Urban Pedestrian 
The success of pedestrianization, or managing the change of an existing road over time, depends on certain principles. Previous studies show that to determine these principles; some quality criteria were required to be designed for pedestrian spaces (Alves \& Ramalho, 2011; Asadi-Shekari, Moeinaddini, \& Zaly Shah, 2015a, 2015b; Blaga, 2013; Cengiz, 2011; Cengiz \& Keçecioğlu Dağlı, 2017; Çol, 2004; Day, Boarnet, Alfonzo, \& Forsyth, 2006; Ewing, Hajrasouliha, Neckerman, Purciel-Hill, \& Greene, 2016; Isaacs, 2000; Khisty, 1994; Moeinaddini, Asadi-Shekari, Sultan, \& Zaly Shah, 2015; Moeinaddini, Asadi-Shekari, \& Zaly Shah, 2014a, 2014b; Sayyadi \& Awasthi, 2012). Numerous studies were also conducted in Turkey for this purpose (Açık Etike \& Erdönmez Dinçer, 2019; Alpak, Düzenli, \& Yılmaz, 2018; Aytaş \& Uzun, 2015; Cengiz, 2011; Cengiz \& Keçecioğlu Dağlı, 2017; Çalışkan, 2011; Kızıloğlu \& Polat, 2020; Özkaynak \& Korkmaz, 2019; Resuloğlu, 2020; Saylan \& Erdönmez Dinçer, 2017; Şenkaynak, 2010; Topçu, 2011; Uzgören \& Erdönmez, 2017). These quality criteria had to meet certain requirements when planning or managing these areas and aim at providing an unrestricted and safe environment for pedestrians. Pedestrian spaces that meet the predefined standards are important for the quality of life, livability, and sustainability of urban centers. Rossini (2019) stated that cities with areas that are inadequate and unsatisfactory in terms of quality and that have standard designs that do not offer social interaction and community activities lack public space culture.

In the process of pedestrianizing existing streets or creating new ones, planners, urban designers, and policymakers need to be aware of the relevant quality criteria. One of the most important steps in this process is to benefit from the experience of pedestrians, the primary users of the areas. This research addresses the streets that are largely allocated to pedestrians and offers four research questions: (1) What are the pedestrian space quality criteria based on user experiences? (2) To what extent do public space quality criteria match those of the pedestrian space? (3) Does the factor analysis method work to determine the quality criteria that pedestrian spaces should have in order to satisfy users? (4) In terms of quality criteria, at what level are Ankara's oldest and most used pedestrian areas?

The study area is Turkey's capital city Ankara's most popular pedestrian streets. There is an urgent requirement for pedestrian spaces in Ankara city center where vehicular traffic is intense. At many such points of the area, where the movement of pedestrians and vehicles coincide, an uncomfortable environment is created for pedestrians. A questionnaire was developed to understand pedestrian experiences in the area. The questionnaire consisted of 22 questions and was administered to 250 people who regularly used this area. The results were statistically evaluated using the process detailed in the study method, and the prominent quality criteria were determined. The results of the research allow decision-makers to recognize and evaluate the strengths of existing pedestrian spaces and to identify their weaknesses. The study also aims at providing information that would serve to build a comprehensive vision and improve the urban pedestrian areas.

\section{Principles and criteria of pedestrian spaces}

Interest in high-quality public spaces and research on their quality criteria have increased globally, and the essential principles of a quality public space are almost determined (Gehl, 2011). According to Mehta $(2007,2014)$ there are four criteria to measure the quality of public spaces, and the measurement method may vary. The criteria are inclusiveness, meaningful activities, safety, and comfort-pleasurability. Many studies have analyzed the quality of urban life under three main headings: functional, visual, and spiritual (Mehan, 2016). The level of functionality of the public open space is related to the differentiation of its separated structural elements (Asadi-Shekari et al., 2015b). One of the indicators of urban quality of life is functional accuracy and communicability. The suitability of social activities and recreation depends on factors such as functional diversity, urban furniture and equipment, the quality of landscape elements, and public safety. Since city centers are

ACE, 15 (41.) CC BY-ND 3.0 ES | UPC Barcelona, España | Determination of Quality Criteria of Urban Pedestrian 3 Spaces. DOI: http://dx.doi.org/10.5821/ace.15.44.9297 
known to be the most active places in the life processes of the society, the use and intensity of urban spaces are increasing from the peripheral region to the center (Bratuškins \& Treija, 2017).

Therefore, the criteria for a successful and quality public space completely or partially apply to pedestrian spaces. According to Madden and Schwartz (2005), the basic requirements for quality public space are primarily accessibility, comfort, socialness, and activities. Alves and Ramalho (2011) stated that the basic considerations for quality public space include comfort, security, accessibility, density, and diversity of utilization. Çalışkan (2011) stated that the design and details of public spaces could be successful only if they provide safety, comfort, and pleasure. According to the Project for Public Spaces (2013), proper public spaces around the world have four common features: they provide comfort, are easily accessible, offer activities in which people can engage themselves, and are sociable places to meet and gather for people. (Bates, 2013) opined that public spaces could be designed based on four pillars: accessibility (pedestrian, bicycle, transit, and parking access to public space), use (land use: density, mixed-use, active uses, and attractions), design (urban form: location, enclosure, visual interest, and amenities such as places to sit, trees, water features, signage, lighting, and pavement treatments), and comfort (preferability in terms of weather and maintenance issues). In addition, several other studies evaluated what streets offer to pedestrians based on criteria such as being comfortable, attractive, secure, and safe (Asadi-Shekari, Moeinaddini, \& Zaly Shah, 2014; Dowling et al., 2008; Florida Department of Transportation, 2009; Fruin, 1971; Miller, Bigelow, \& Garber, 2000; Moeinaddini, Asadi-Shekari, Ismail, \& Zaly Shah, 2013; Muraleetharan, Adachi, Hagiwara, \& Kagaya, 2005; Muraleetharan, Adachi, Hagiwara, Kagaya, \& Kawamura, 2004; National Research Council, 2000; Sarkar, 2003; Tan, Wang, Lu, \& Bian, 2007).

From the studies on pedestrian spaces, common criteria are gathered under the headings of "high densities, pedestrian-friendly design, pedestrian-oriented street pattern, mix-uses, and parking regulations." For all the places, including plazas, squares, streets, or parks, the comfort and safety of pedestrians stand out as the topmost requirement. The subcomponents of comfort and safety of pedestrians are topography, weather, distance, air pollution, noise, signposting, pavements, urban furniture, vegetation, bicycle lanes, shopping opportunities, restaurants, playgrounds, location, and architectural or urban design (Blaga, 2013).

Some researchers have included the planning and design principles of pedestrian spaces in their work. For example, according to Blaga (2013), a pedestrian space must not be separated from urban transportation and environmental architecture and should include the following criteria: not disrupting the integrity of the urban structure, appropriately located with a separate identity and with its boundaries, public transportation means, easily accessible, and car parking areas. Alves and Ramalho (2011) stated that while designing pedestrian spaces, the planners should leave sufficient spaces, which meet both functional and formal requirements. The following are criteria required to meet certain functional requirements of pedestrian spaces: it should be a space where various activities are interconnected by routes; routes and spaces should not be corrupted by shortcuts; surface textures and forms must be both functionally correct and aesthetic; and at intersections with other routes, pedestrians must have the right of way and the level must be preserved. In some studies, aesthetic criteria such as plants, cleanliness, maintenance, design, and amenities are accepted as parameters (Day et al., 2006; Pikora et al., 2006). However, according to Ewing et al. (2016), designing of pedestrian spaces should include components that positively affect the pedestrian experience. Components such as comfort and safety, well-defined open spaces that give a sense of clarity, similar architectural surfaces and details, focal points and benchmarks, and beginnings, endings, and vistas along the route (Isaacs, 2000), have a positive impact on the pedestrian experience.

ACE, 15 (41.) CC BY-ND 3.0 ES | UPC Barcelona, España | Determination of Quality Criteria of Urban Pedestrian 4 Spaces. DOI: http://dx.doi.org/10.5821/ace.15.44.9297 
Sayyadi and Awasthi (2012) stated that creating safe and proper pedestrian zones for malls, areas hosting entertainment and leisure activities, and people-friendly environments would be beneficial for the society and its environment. Cengiz and Keçecioğlu Dağlı (2017) reported that to ensure a comfortable pedestrian walk, it is important to design well-maintained and sustainable spaces where vehicular movements are reduced, pedestrian-priority spaces are provided, social activities are allowed to increase, and people have strong communication with each other. Those spaces should also be accessible and usable for everyone, reflecting the character of the area. In addition, to ensure the safety of pedestrians and bicyclists, working toward improving the infrastructure around the area is important (Asadi-Shekari et al., 2015a, 2015b; Moeinaddini et al., 2015; Moeinaddini et al., 2014a, 2014b). One of the elements of Khisty (1994) method, which determines the qualitative level of service, is the security measure that distinguishes between pedestrian and vehicular movement safety. Cengiz (2011) carried out a study that examined the design of pedestrian space and revealed that pedestrians used specific areas for bank transactions, shopping, food and beverage, resting, walking, and entertainment. These areas were disturbed by crowds, visual pollution, noise and air pollution, lack of security, hawkers, and shops located on the walking path. When asked about their expectations, the pedestrians stated that exhibitions, street activities, seating units, road trees, and plastic art items should be increased.

\section{The Turkey context}

The times, goals, and forms of pedestrianization work differ from country to country. The need for pedestrianization in Turkey was first addressed in the International Road Congress convened in Istanbul in 1955 (Birişçi Yıldırım, Özel, \& Oktay, 2014). In Turkey, the 1963-1968 timeframe is the period when underpasses and overpasses were constructed for both pedestrians and motor vehicles. This effort was based on the concern that vehicles restrict pedestrian movement. However, in all these studies, the primary goal was to relieve vehicular traffic, and there was very little focus on pedestrian movement (Çol, 2004). Starting from the 1970s, pedestrianization policies began to be implemented in order to promote a new lifestyle in urban centers and provide livable areas in the process of urban development and transformation (Özkaynak \& Korkmaz, 2019). With the neoliberal policies pursued after 1980, urban areas began to be commodified and were handled with a purely physical space dimension. This tendency has turned the concept of space quality in public open spaces and the relationship of the concept with urban space activities into issues that need to be emphasized (Uzgören \& Erdönmez, 2017).

The first applications in Ankara are the works initiated by the municipality in 1978, with the idea of increasing public spaces and green spaces and strengthening the declining social life (Cengiz, 2011; Zafer, 1998). With the sudden and unplanned transformation of the city center, Kızılay was incapable of responding to the needs of the increasing population. As part of the transformation, residences located on some streets were converted into businesses. To facilitate the increased movement of vehicles, the pavement width was reduced, and bus stops were made to occupy the pavements. These changes directed pedestrians to İmir, Sakarya, and Yüksel streets (Iranmanesh, 2008). Many streets that were connected to Kizılay Square in 1979 were transformed into pedestrian spaces (Özkaynak \& Korkmaz, 2019). In addition to walking routes, seating groups, pools, fountains, exhibitions, and sales units were designed in the project prepared for Sakarya Street and its surroundings (Öncü Yıldız, 2017). Izmir Street, which is a commercial area with many shops, was pedestrianized in 1980, and the final version of pedestrianization was carried out in 2003 with a new project (Yalçınkaya, 2007). Within the framework of the Pedestrian Spaces Regulation of the Ankara Metropolitan Municipality that came into effect in 1989, new pedestrian streets were proposed, most of which were on the west side of Ataturk Boulevard; however, only a few of them were actualized (Kaplan \& Acuner, 2005). In 2004, the Planning, Rehabilitation, and Conservation of Ankara Old City Pattern 
Project were approved, and it was put into practice in 2007. Within the scope of the project, in Hamamönü, facade and street improvements were made, old Ankara houses were restored, and the majority of the streets were reserved for pedestrians (Hazır, 2019).

Studies on the extent that public spaces meet quality criteria are quite new in Turkey. Topçu (2011) administered a questionnaire to 1,024 participants in his study comparing 12 shopping places in Bursa, Gaziantep, Izmir, and Konya in terms of spatial quality. In the questionnaire, questions were asked under four main criteria, namely, social quality, functional competence, visual-aesthetic quality, and cultural-spatial satisfaction, and 33 sub-criteria. The results were analyzed through some statistical analysis, such as crosstabs, mean values, logic model, and analytical hierarchy process model. Saylan and Erdönmez Dinçer (2017) administered a questionnaire, consisting of 26 questions, to 44 users in their study on "place quality in the use of public spaces" in Historical Peninsula Eminönü, one of the first settlements in Istanbul. The questions in the survey were oriented toward access, leisure, pedestrian spaces, lighting, cleaning, shading, plants, routing, traffic, parking, disabled access, use purpose, and floor coverings. Results were given as percentage distribution. Uzgören and Erdönmez (2017) compared two parks in Istanbul in terms of the relationship between the quality of space and urban activities. Seventy people participated in the survey. Questions were asked under the topics of access and connections, usage and activities, sociability, comfort, and image, and the results were presented as percentages. Alpak et al. (2018) examined the quality of public open space and its effects on social interaction in a square and a park in Trabzon. For this purpose, 140 people were surveyed, and 34 questions were asked. As a result of factor analysis, it was seen that the parameters were collected under five factors. These are inclusiveness, meaningful activities, comfort, safety, and pleasurability. In the analysis of the survey results, a principal component analysis was used. According to the research, the level of social interaction increases as public space quality increases. Açık Etike and Erdönmez Dinçer (2019) used the Project for Public Spaces' parameters of sociality, usage-activities, accessibility-connections, and comfort-image as quality criteria in their study comparing Istanbul's Beşiktaş and Venice's San Marco squares in terms of public space quality. Data were obtained through observation, literature review, photographing, and process records. Kızıloğlu and Polat (2020) discussed a square and a street in Bursa in their work on participatory design in public spaces. For measuring public space quality, they used the Place Standard Tool developed by Architecture and Design Scotland (2020). The Place Standard Tool diagram consists of circulation, public transport, traffic and parking lots, streets and spaces, natural areas, playgrounds and recreation, facilities, business, and local economy, housing and society, social interaction, identity and place attachment, safety, maintenance, and impact and control. The questionnaire, for which questions were created based on these 14 topics, was administered to 100 people. With the results given in percentages, a diagram containing views on the social, physical, and economic characteristics of the area was obtained. Resuloğlu (2020) examined the features aimed at improving the quality of life on Tunalı Hilmi Street, Ankara. For this purpose, a total of 19 physical features under the main components of design elements, location, and connecting spaces and eight features related to the environment were evaluated by the users. One-hundred people answered the questionnaire.

Most studies on determining the quality criteria levels for specifically pedestrian spaces are recent. Çol (2004), determined the standards of pedestrian zone design as being safe, being included in the transportation network, being easy and comfortable to use, offering appropriate air conditioning, containing attractive and beautiful places, giving a sense of space with structural elements, having urban furniture and planting, being free of unpleasant images, having properly designed car parks, and being easily accessible and usable for disabled people. In the study, a survey was conducted with 28 workplaces and 75 pedestrians to compare the situation of Marmara Street, İstanbul, before and after pedestrianization. The results were given as percentage distributions. Şenkaynak (2010) evaluated the success of pedestrianization in three streets of istanbul in terms of urban landscape planning. To this end, a questionnaire was administered to 300 participants. 33 questions were asked

ACE, 15 (44.) CC BY-ND 3.0 ES | UPC Barcelona, España | Determination of Quality Criteria of Urban Pedestrian 6 Spaces. DOI: http://dx.doi.org/10.5821/ace.15.44.9297 
regarding visiting relationships; usage, activity, and facility relations; circulation properties; general characteristics; and socio-economic structure. In the analysis of the data, Chi-Square test was used to compare two or more datasets and to question whether there was a significant relationship between the variables. Cengiz (2011), examined the pedestrian zone design of Hükümet Street, Bartın; determined the opinions and needs of the users; and analyzed whether the current situation complies with the pedestrian space design criteria. For this purpose, a questionnaire, which was compiled from related literature, was administered to 100 users. They answered questions on the purpose of use, crowdedness, image-noise-air pollution, safety, and event-activity-plant-plastic art item expectations. Results were given as percentage distribution. Çalışkan (2011) used the observation and questionnaire method in her study that examined a pedestrianization project in Historical Peninsula Eminönü. Within the scope of observation, photographing, visual analysis, and pedestrian counting were carried out, and the obtained data were evaluated by the author in accordance with the space quality criteria of Gehl. A survey was conducted with 127 people, including 102 users and 25 traders, and the questions were designed under four main headings based on Gehl's quality criteria: accessibility, use-activities, comfort, and sociability-interaction. The results were analyzed by crossquery using relational taxonomy classification and exploratory data analysis method. Aytaş and Uzun (2015) examined the relationship between expert opinion-based parameters and user-based parameters with Pearson's correlation analysis in their study aimed at determining the visual landscape quality of pedestrian areas in Düzce city center. Forty visual landscape feature criteria were divided into nine groups and evaluated by the expert group. These are naturalness, complexity, consistency, image, discomfort, seasonality, measure, manageability, and historicity. The criteria were subjected to factor analysis and were collected under three headings: naturalness, manageability, and historicity. Eighteen photographs taken from the area were shown to the user group, and questions were asked about comfort, clarity, compatibility, distraction, naturalness, appreciation, and safety criteria. After evaluating the received answers with factor analysis, two titles were identified as perception and appreciation. Özkaynak and Korkmaz (2019) conducted a study examining the problems in pedestrianized areas in the case of Zafer Square, Konya. The problems identified through site survey and observation were gathered under five main headings: design, accessibility, landscape, facades, and building materials.

\section{Material and method}

According to Zafer (1996) Sakarya Street is the first pedestrianized street in Kızılay, Ankara. It was pedestrianized in 1979 to increase the number of strolling areas and green spaces for the locals and to strengthen the deteriorating social life. For this study, research was conducted on Sakarya Street and eight streets in its vicinity. They are izmir-1 Street in Kızılay District; Tuna, Selanik, Sakarya, Inkılap, and Bayındır-1 streets in Cumhuriyet District; and Yüksel, Karanfil, and Konur streets in Meşrutiyet District (Figure 1), all of which are located in the Çankaya subprovince of Ankara. The reasons for selecting these streets are that they are centrally located urban streets and show remarkable diversity in terms of user characteristics and the activities offered.

This study aims to determine the pedestrian space quality criteria based on the views of pedestrians as primary users. Therefore, a questionnaire-based study was conducted in nine pedestrian spaces (Figure 2). The questions were collected from existing literature and related references, which are mentioned in the second and third sections of this study. Specifically, Alves and Ramalho (2011); Asadi-Shekari et al. (2015a, 2015b); Blaga (2013); Çalışkan (2011); Day et al. (2006); Gehl (2011); Mehta (2007, 2014); Project for Public Spaces (2013) were the studies that guided us during the process of creating relevant questions for the questionnaire and designing the evaluation method. To summarize some of the studies referenced in this research, according to Gehl (2011), the essential principles of a quality public space are related to protection from crime, vehicular traffic, and adverse climatic 


\section{ACE Architecture, City and Environment}

conditions; access to good weather; aesthetic quality; sense of place; events and activities; functions; walking, standing, and sitting opportunities; conditions for seeing, hearing, and talking; dimensions and facades of buildings; addressing different age groups; access from residential areas, and so forth. In his study of three different streets in the Boston metropolitan area, Mehta (2007) collected data through observations of resident, worker, and visitor behaviors and analyzed them using quantitative methods. Eleven characteristics of the street environment were identified based on the literature review and the observations conducted by the author. These are block variety, independent uses, permeability, personalization, community places, articulation, public seats, commercial seats, sidewalk width, shade, and street furniture and physical artifacts. As a result of factor analysis, four quality factors were obtained: "land use - quality factor 1," "physical - quality factor 2 and 3," "social - quality factor 4." In another study, Mehta (2014) created an index based on an empirical evaluation to measure the quality of public space. According to the study conducted in four public spaces in Tampa, Florida, public spaces have four dimensions: inclusiveness, meaningful activities, safety, and comfort and pleasurability. In a study by Alves and Ramalho (2011), which discussed the application principles for pedestrian spaces, the main factors indicated for public space vitality are security, density, diversity of activities and uses, accessibility, and comfort. The measurable attributes under these main factors are criminality data, hygienic level, environmental indicators, surface, noise level, type of street furniture, type of greenery, degree of lighting, casualties, and serial vision and focal point. Asadi-Shekari et al. (2015a, 2015b) carried out surveys measuring pedestrian safety in the streets in two different studies. Blaga (2013) stated that pedestrian zones are important urban strategies and the quality of a pedestrian zone depends on safety and comfort.

Figure 1. Location of the study area

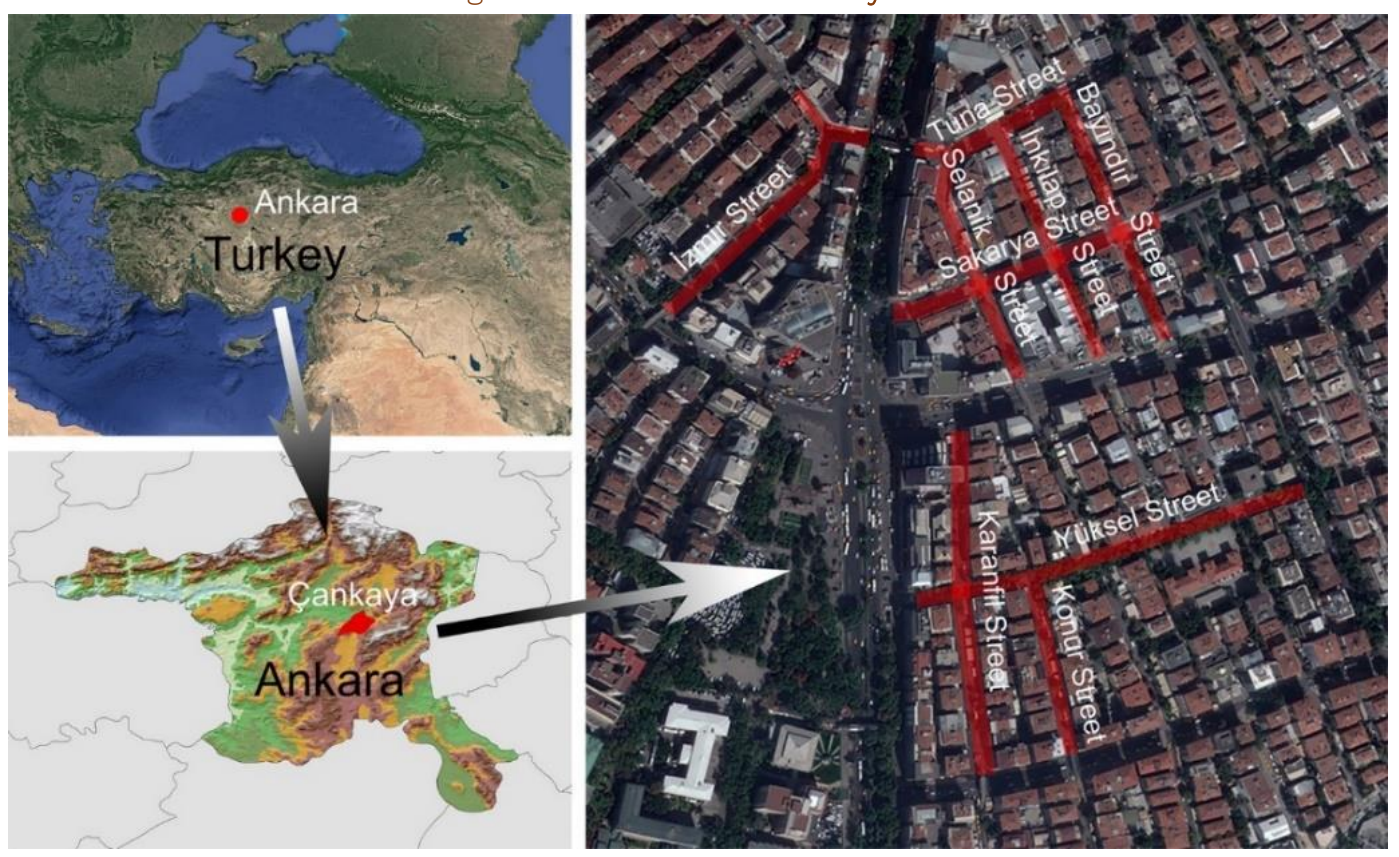

Source: Created by the authors using Google Earth images.

Security factors are about topography, weather, the distance the user needs to cover, air pollution, noise, and vehicular traffic; comfort factors are signposting of routes, covered walkways, large pavements, proper street furniture and vegetation, relaxing and health purposes, lights, trees, parking, shopping, playgrounds, and leisure activities. Day et al. (2006) conducted a case study in IrvineMinnesota to measure the level of active living support of built environments. For this purpose, they created an inventory through focus group interviews, a panel of experts, and field testing. According to them, factors that may influence physical activity are accessibility (transportation, street pattern, 


\section{ACE Architecture, City and Environment}

slope, walkways, physical barriers, etc.), pleasurability (aesthetic appeal, attractive destinations, comfort, etc.), and safety from traffic and crime. Project for Public Spaces (2013) stated that successful public spaces have four quality criteria: accessible, engaging in activities, comfortable, and sociable. The questions required to measure them are related to visibility, connections, easy walking, sidewalks, disabled people, proper routes, transportation options, destinations, first impression, seating, cleaning, safety, photo opportunities, vehicles, activities, women-men ratio, age groups, duration of use, socializing, management, meeting friends, interaction, knowing each other, being proud of the place, happiness, regular use, ethnic groups, and litter tendency.
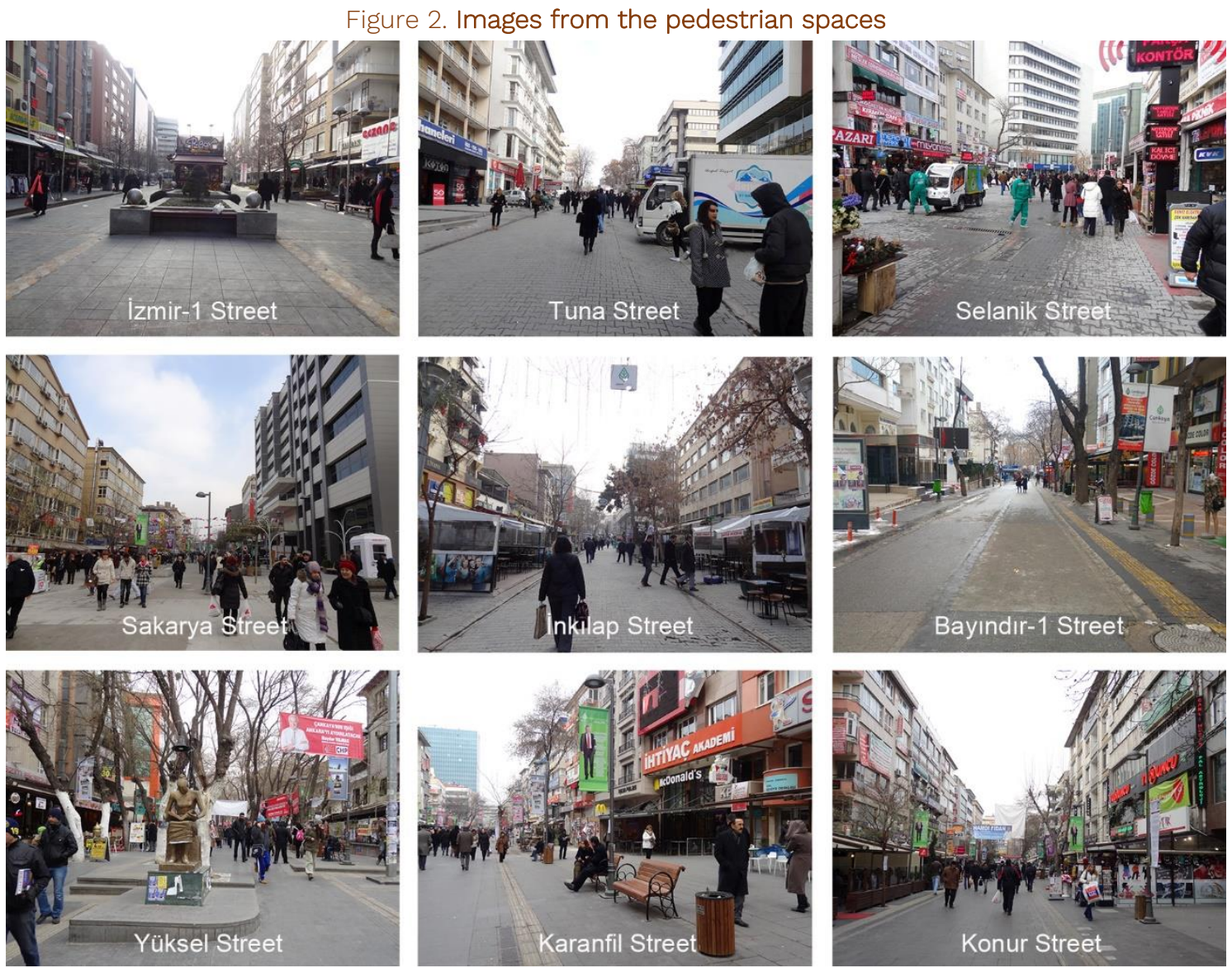

Source: Taken by the authors.

Although very few of these pedestrian streets are physically separate, they are in the same city center and connected to each other. The selected streets have common characteristics such as central location, urban space, diversity of activities, easy access, diversity of user profiles, subsequent pedestrianization, historical space, user density, and similarity in building facades. The users of these selected streets were asked to answer 22 questions collected from similar studies, and quality criteria were determined by analyzing the findings by factor analysis method.

For this research, a survey, which aimed to determine the quality criteria for urban pedestrian spaces in line with the users' point of view, was conducted with the users of the areas as participants. The survey was completed by working with 10 university students in the field, along with the participation of both the authors. The survey sample included 250 individuals with a confidence level of $94 \%$ ( $\alpha=$

ACE, 15 (44.) CC BY-ND 3.0 ES | UPC Barcelona, España | Determination of Quality Criteria of Urban Pedestrian 9 Spaces. DOI: http://dx.doi.org/10.5821/ace.15.44.9297 
0.06), but the size decreased to 224 with the removal of invalid forms. Simple random sampling method was used to represent the entire population. The sampling formula is;

$$
n=\frac{t^{2} \cdot q \cdot p}{d^{2}}
$$

$\mathrm{n}=$ Number of individuals to be sampled

$\mathrm{t}=$ Critical value for a $94 \%$ confidence level according to $\mathrm{t}$ table $(\mathrm{t}=1.96)$

q. $p=$ Universe variance $(p=0.5 / q=0.5)$

$d=$ Sampling error $(d=0.06)$

In the first part of the survey, the participants' demographic information, the time they spent to reach the pedestrian space, the time at which they used the pedestrian space the most, and their purpose of using pedestrian spaces were investigated. In the second part, the participants were asked to score the features that the pedestrian space should have according to their importance. In the third part, they gave points based on the extent that the pedestrian zones met the quality criteria.

Twenty-two statements were added in the second part of the survey to determine the quality criteria of pedestrian spaces. These statements were compiled from similar research conducted earlier, which referred to the users' opinions. A five-point Likert-type scale was used in the scoring of the statements by the users. Factor analysis was then performed using these data. In this process, four statements with eigenvalue less than 1 and factor loading value less than 0.40 were excluded from the analysis. The remaining 18 statements were divided into five classes by the SPSS program, and thereby, the main criteria were revealed. Cronbach's alpha test was performed to estimate the reliability and internal consistency for these factor scores.

In the third part of the survey formulated to determine the compliance of the streets with the quality criteria, the users evaluated the pedestrian spaces in the context of the sub-criteria formed by the 18 statements. During the analysis phase, four main criteria were taken into consideration. The questions related to the accessibility criterion, included in the questionnaire, were based on general accessibility to the area. However, this criterion has been excluded from this stage since the streets where the study is conducted are interconnected and have public transport stops in the immediate vicinity of all.

It is considered that the importance level of sub-criteria may change. Each sub-criterion was given a weight score of 1 to 3 by a group of six experts consisting of landscape architects and architects. Quality scores were calculated by multiplying the average of the users' evaluations with the weight scores given by the experts. These scores have been converted into percentages so that the quality criteria are comparable.

The Place Standard Tool diagram developed by Architecture and Design Scotland was adapted for this study to measure the quality levels and to easily detect the strengths and weaknesses of each street in the study area Architecture and Design Scotland (2020). At this stage, the survey containing 15 sub-criteria was evaluated, and diagrams were created with the resulting means.

\section{Findings}

Of the 250 participants, 35.3\% were female and 64.7\% were male. Among them, 44.2\% were aged 1625 years, 33.5\% were aged 26-40 years, 19.2\% were aged $41-60$ years, and 3.1\% were aged 60 years and above. Among them, 11.6\% were elementary school graduates, $47.8 \%$ were high school graduates,

ACE, 15 (44.) CC BY-ND 3.0 ES | UPC Barcelona, España | Determination of Quality Criteria of Urban Pedestrian 10 Spaces. DOI: http://dx.doi.org/10.5821/ace.15.44.9297 
$36.2 \%$ were university graduates, and $4.5 \%$ had a postgraduate degree. A total of $22.3 \%$ of the participants reached the pedestrian space on which the research was conducted in 0-15 min, 39.7\% in $16-30 \mathrm{~min}, 28.1 \%$ in $60 \mathrm{~min}$, and $9.8 \%$ in more than $60 \mathrm{~min}$.

The distribution of the participants according to their purpose of using the pedestrian space is shown in Table 1. Participants use the pedestrian zones mostly for work purposes (43.8\%), as a passageway (28.1\%), as a shopping area (21.9\%), and as meeting points (21.4\%). There are statistically significant differences between men and women in terms of the use of the pedestrian space for work, meeting point, and shopping purposes $(p<0.05)$ (Table 1). Accordingly, men use pedestrian space more for work and meeting point purposes. On the other hand, women use pedestrian space more for shopping purposes.

Table 1. The distribution of the participants' purpose of use according to gender

\begin{tabular}{|c|c|c|c|c|c|}
\hline & & \multicolumn{2}{|c|}{ Gender } & \multirow{2}{*}{ Total } & \\
\hline & & Women & Men & & \\
\hline \multirow[b]{2}{*}{ Passage way } & $\mathrm{N}$ & 26 & 37 & 63 & \multirow{2}{*}{$\begin{array}{l}\text { Chi-Square: } 1.383 \\
\text { df } \\
p\end{array}$} \\
\hline & $\%$ & 41.30 & 58.70 & 100 & \\
\hline \multirow[b]{2}{*}{ Work } & $N$ & 24 & 74 & 98 & \multirow{2}{*}{$\begin{array}{l}\text { Chi-Square: } 8.865 \\
\text { df } \\
p \\
p\end{array}$} \\
\hline & $\%$ & 25.50 & 75.50 & 100 & \\
\hline \multirow{2}{*}{ Meeting point } & $N$ & 23 & 25 & 48 & \multirow{2}{*}{$\begin{array}{ll}\text { Chi-Square: } & 4.281 \\
\text { df } & : 1 \\
p & : 0.039 *\end{array}$} \\
\hline & $\%$ & 47.90 & 52.10 & 100 & \\
\hline \multirow{2}{*}{ Resting } & $N$ & 4 & 13 & 17 & \multirow{2}{*}{$\begin{array}{l}\text { Chi-Square: } 1.110 \\
\text { df } \\
\mathrm{p} \\
: 1 \\
: 0.292\end{array}$} \\
\hline & $\%$ & 23.50 & 76.50 & 100 & \\
\hline \multirow{2}{*}{ Strolling/walking } & $N$ & 17 & 22 & 39 & \multirow{2}{*}{$\begin{array}{ll}\text { Chi-Square: } & 1.432 \\
\text { df } & : 1 \\
p & : 0.231\end{array}$} \\
\hline & $\%$ & 43.60 & 56.40 & 100 & \\
\hline \multirow[b]{2}{*}{ Watching around } & $N$ & 4 & 3 & 7 & \multirow{2}{*}{$\begin{array}{l}\text { Chi-Square: } 1.515 \\
\text { df } \\
p \\
p\end{array}$} \\
\hline & $\%$ & 57.10 & 42.90 & 100 & \\
\hline \multirow{2}{*}{$\begin{array}{c}\text { Reading } \\
\text { newspaper/book }\end{array}$} & $N$ & 3 & 6 & 9 & \multirow{2}{*}{$\begin{array}{ll}\text { Chi-Square: } & 0.015 \\
\text { df } & : 1 \\
p & : 0.901\end{array}$} \\
\hline & $\%$ & 33.30 & 66.70 & 100 & \\
\hline \multirow[b]{2}{*}{ Food \& beverage } & $N$ & 19 & 20 & 39 & \multirow{2}{*}{$\begin{array}{ll}\text { Chi-Square: } & 3.742 \\
\text { df } & : 1 \\
p & : 0.053\end{array}$} \\
\hline & $\%$ & 48.70 & 51.30 & 100 & \\
\hline \multirow[b]{2}{*}{ Shopping } & $N$ & 26 & 23 & 49 & \multirow{2}{*}{$\begin{array}{l}\text { Chi-Square: } 8.698 \\
\text { df } \\
\text { p }\end{array}$} \\
\hline & $\%$ & 53.10 & 46.90 & 100 & \\
\hline \multirow{2}{*}{$\begin{array}{c}\text { Social and cultural } \\
\text { activities }\end{array}$} & $N$ & 14 & 25 & 39 & \multirow{2}{*}{$\begin{array}{l}\text { Chi-Square: } 0.008 \\
\text { df } \\
p \\
p\end{array}$} \\
\hline & $\%$ & 35.90 & 64.10 & 100 & \\
\hline
\end{tabular}

Source: Created by the authors using SPSS data analysis.

The participants were asked to rate the elements associated with the pedestrian spaces in order of importance, and the results were grouped using factor analysis. The value of the Kaiser-Meyer-Olkin (KMO) measure of sampling adequacy, which shows the adequacy of the data for factor analysis, must be higher than 0.5. The KMO value for the question described in the questionnaire is 0.802 . Factor analysis is performed using varimax rotation. Factor analysis improved validity by eliminating four items with eigenvalues less than 1 and factor loadings less than 0.40. The items that were removed were "bicycle park," "guide signs," "landscape," and "information and advertising boards." The 
resulting index, including 18 items, could be further whittled down into five factors: design, maintenance, activities, accessibility, and safety. Cronbach's $\alpha$ values of these factors are 0.76, 0.69, $0.74,0.63$, and 0.50 , respectively. These factors explained $58.49 \%$ of the variance in responses (Table 3). It is the accessibility factor that has the highest mean among the factors (M: 4.52). It is followed by design (M: 4.23), maintenance (M: 4.09), activities (M: 3.98), and safety (M: 3.60) factors (Table 2).

Table 2. Factor analysis of the pedestrian area quality criteria

\begin{tabular}{|c|c|c|c|c|c|}
\hline & Mean & SD & $\begin{array}{l}\text { Factor } \\
\text { loading }\end{array}$ & $\begin{array}{c}\text { Variance } \\
\text { explained } \\
(\%)\end{array}$ & $\begin{array}{c}\text { Cronbach } \\
(\alpha)\end{array}$ \\
\hline Factor 1: Design & 4.23 & 0.75 & & 14.82 & 0.76 \\
\hline Urban furniture & 4.63 & 0.84 & 0.58 & & \\
\hline Floor coverings & 4.50 & 1.04 & 0.76 & & \\
\hline Shops' usage style of pedestrian area & 4.31 & 1.14 & 0.62 & & \\
\hline Green areas/Planting & 4.31 & 1.13 & 0.49 & & \\
\hline Water elements (Ornamental ponds, fountains etc.) & 4.19 & 1.20 & 0.55 & & \\
\hline Plastic elements (statue, monument, clock etc.) & 3.96 & 1.25 & 0.56 & & \\
\hline Structural shading elements & 3.67 & 1.45 & 0.45 & & \\
\hline Factor 2: Maintenance & 4.09 & 0.95 & & 13.54 & 0.69 \\
\hline Maintenance of structural elements & 4.14 & 1.16 & 0.77 & & \\
\hline Maintenance of plants & 4.14 & 1.18 & 0.76 & & \\
\hline Cleanliness & 3.99 & 1.30 & 0.45 & & \\
\hline Factor 3: Activities & 3.98 & 1.15 & & 11.11 & 0.74 \\
\hline Social activities & 4.08 & 1.23 & 0.82 & & \\
\hline Cultural activities & 3.88 & 1.35 & 0.83 & & \\
\hline Factor 4: Accessibility & 4.52 & 0.65 & & 10.02 & 0.63 \\
\hline Convenience of access & 4.57 & 0.85 & 0.68 & & \\
\hline Opportunity to access to neighborhood by walking & 4.44 & 0.90 & 0.65 & & \\
\hline Having a central location & 4.55 & 0.89 & 0.70 & & \\
\hline Factor 5: Safety & 3.60 & 0.74 & & 9.00 & 0.50 \\
\hline Security (theft, petty crime etc.) & 4.51 & 0.89 & 0.84 & & \\
\hline Lightening & 3.16 & 1.43 & 0.84 & & \\
\hline To be sheltered from the weather conditions & 3.11 & 1.33 & 0.62 & & \\
\hline
\end{tabular}

Source: Created by the authors using SPSS data analysis.

Accessibility is seen as the most important quality criterion because the current pedestrian spaces are mostly used for working, passing, and meeting, and they are also easily accessible from all over the city. The users also point out design (Figures 3 and 4) and maintenance as important quality criteria because they use these streets for resting, strolling, walking, watching around, reading newspapers and books, and consuming food and beverage (Figure 5). Findings show that the diversity of socio-cultural activities and the possibility of shopping offered by the pedestrian spaces attract users to these areas. This requires activities to be treated as a separate quality criterion (Figure 6).

Figure 3. Images from the pedestrian spaces related to design
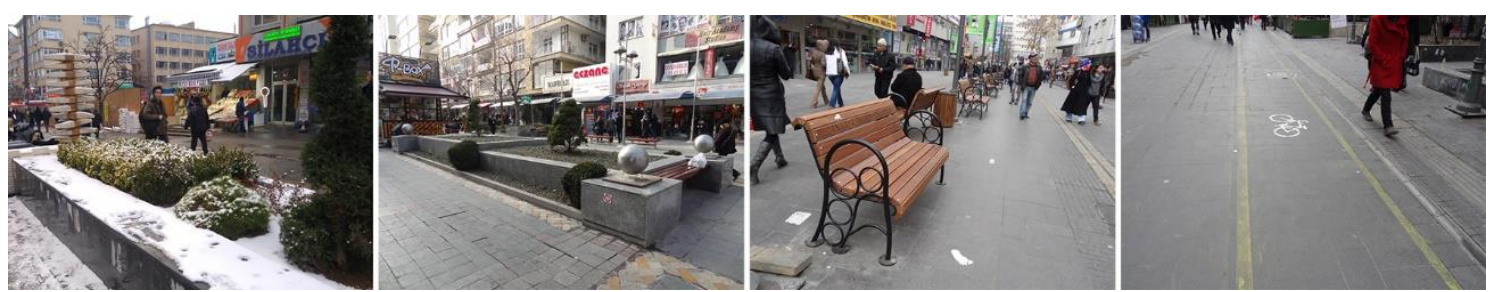

Source: Taken by the authors.

ACE, 15 (44.) CC BY-ND 3.0 ES | UPC Barcelona, España | Determination of Quality Criteria of Urban Pedestrian

Spaces. DOI: $\underline{\text { htp://dx.doi.org/10.5821/ace.15.44.9297 }}$ 
Figure 4. Images of the plastic art items in the pedestrian spaces
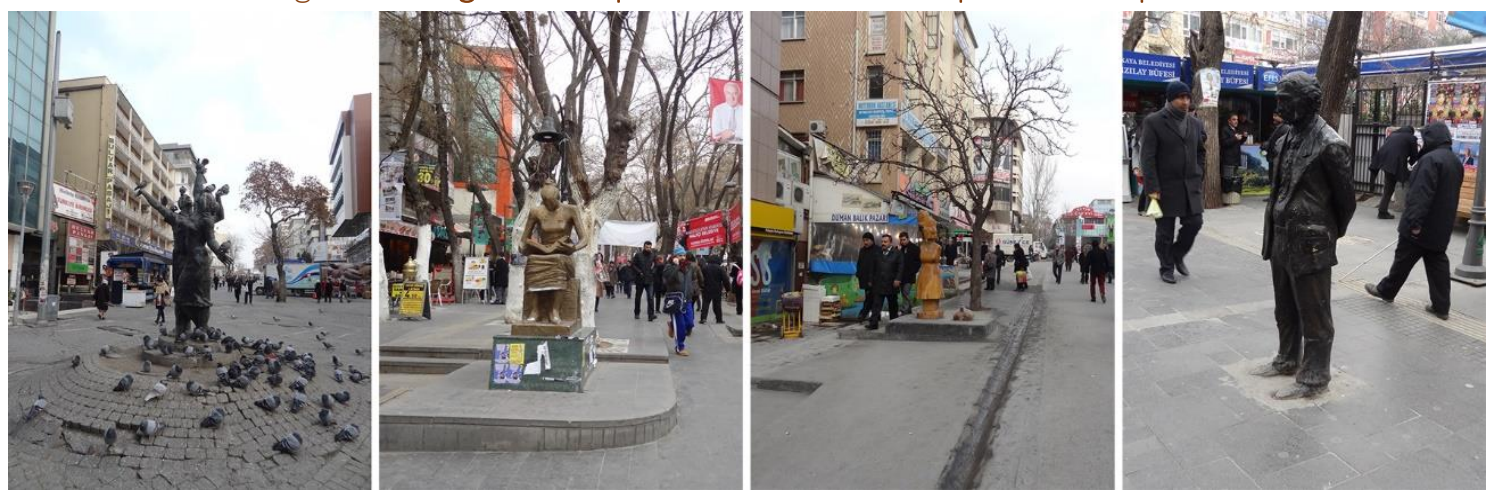

Source: Taken by the authors.

Figure 5. Images from the pedestrian spaces related to maintenance
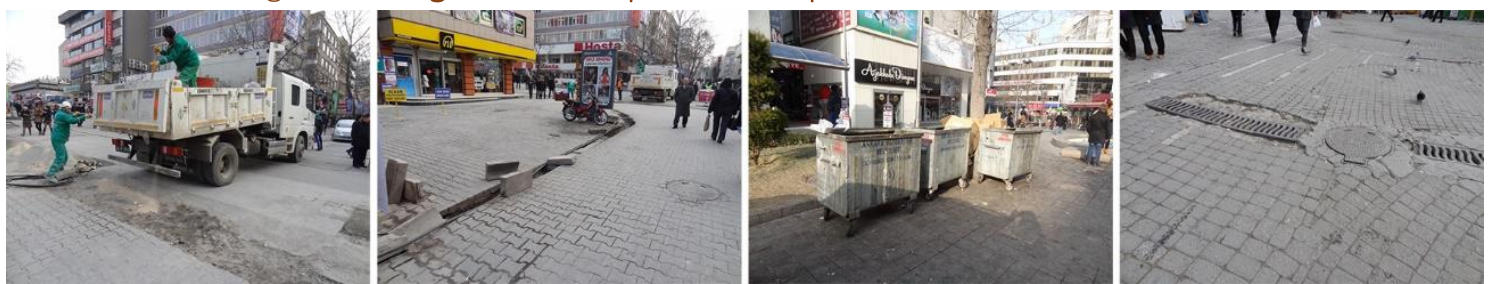

Source: Taken by the authors.

Figure 6. Images from the pedestrian spaces related to activities
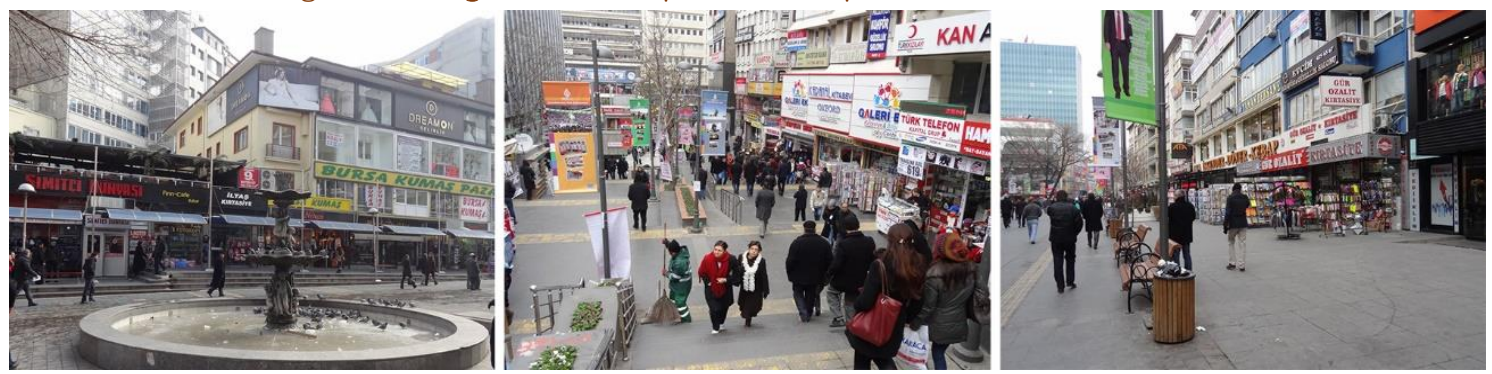

Source: Taken by the authors.

People are spending time mandatorily or willingly in the pedestrian spaces in all seasons and at various times of the day. Thus, components such as security, lighting, and protection against adverse weather conditions can be considered under the safety criterion (Figure 7).

Figure 7. Images from the pedestrian spaces related to safety
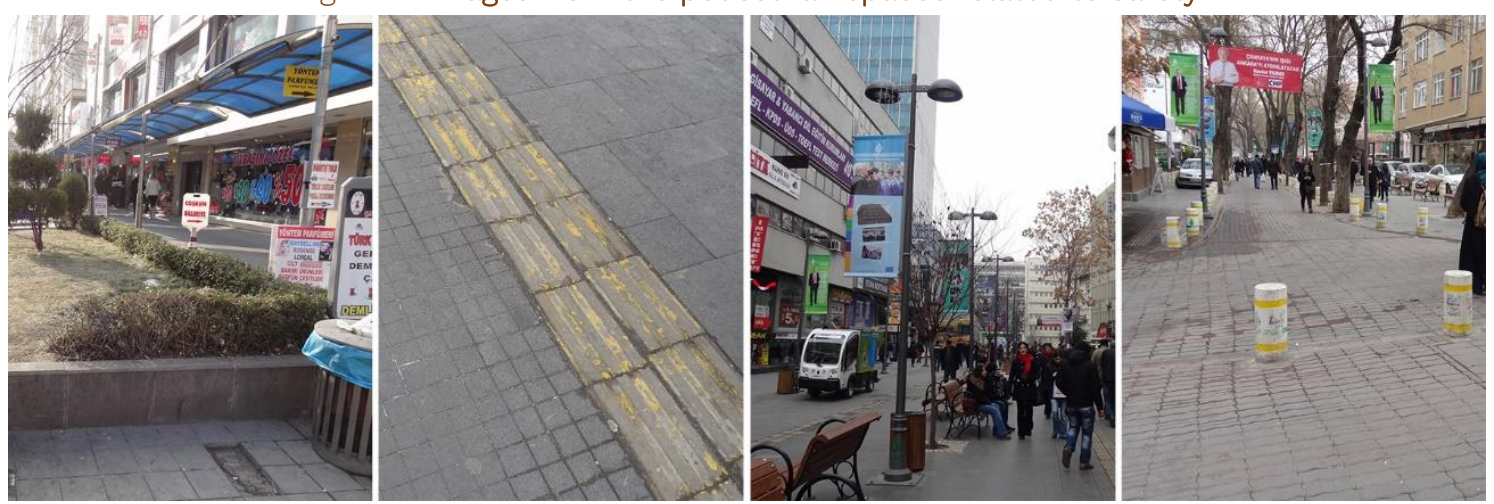

Source: Taken by the authors.

ACE, 15 (44.) CC BY-ND 3.0 ES | UPC Barcelona, España | Determination of Quality Criteria of Urban Pedestrian

Spaces. DOI: http://dx.doi.org/10.5821/ace.15.44.9297 
There are no significant differences between females and males in terms of design, activities, maintenance, and safety factors related to the pedestrian space $(p>0.05)$. Besides, there are no significant differences between the participants of different ages in terms of the factors attained as a result of the one-way analysis of variance ( $p>0.05)$ (Table 3).

Table 3. Investigation of whether or not there is a difference based on gender and age for pedestrian area quality criteria

\begin{tabular}{|c|c|c|c|c|c|c|c|c|c|c|c|c|}
\hline & & & \multicolumn{2}{|c|}{ Design } & \multicolumn{2}{|c|}{ Maintenance } & \multicolumn{2}{|c|}{ Activities } & \multicolumn{2}{|c|}{ Accessibility } & \multicolumn{2}{|c|}{ Safety } \\
\hline & $\mathrm{N}$ & $\%$ & Mean & SD & Mean & SD & Mean & SD & Mean & SD & Mean & SD \\
\hline \multicolumn{13}{|l|}{ Gender } \\
\hline Female & 79 & 35.30 & 4.31 & 0.67 & 4.13 & 0.93 & 4.13 & 1.10 & 4.45 & 0.71 & 3.70 & 0.81 \\
\hline Male & 145 & 64.70 & 4.18 & 0.77 & 4.07 & 0.97 & 3.90 & 1.18 & 4.56 & 0.64 & 3.54 & 0.90 \\
\hline & & & \multicolumn{2}{|c|}{ t: 1.34} & \multicolumn{2}{|c|}{ t: 0.45} & \multicolumn{2}{|c|}{ t: 1.43} & \multicolumn{2}{|c|}{$\mathrm{t}: 1.10$} & \multicolumn{2}{|c|}{ t: 1.30} \\
\hline & & & \multicolumn{2}{|c|}{ p: 0.182} & \multicolumn{2}{|c|}{ p: 0.654} & \multicolumn{2}{|c|}{ p: 0.154} & \multicolumn{2}{|c|}{ p: 0.271} & \multicolumn{2}{|c|}{ p: 0.196} \\
\hline \multicolumn{13}{|l|}{ Age } \\
\hline $16-25$ & 99 & 44.20 & 4.13 & 0.79 & 4.04 & 1.00 & 4.08 & 1.16 & 4.51 & 0.66 & 3.52 & 0.92 \\
\hline $26-40$ & 75 & 33.50 & 4.20 & 0.80 & 4.12 & 0.97 & 3.97 & 1.07 & 4.52 & 0.73 & 3.75 & 0.78 \\
\hline $41-60$ & 43 & 19.20 & 4.32 & 0.45 & 4.32 & 0.84 & 3.81 & 1.26 & 4.55 & 0.57 & 3.46 & 0.90 \\
\hline$\geq 61$ & 7 & 3.10 & 4.55 & 0.49 & 3.86 & 0.92 & 3.57 & 1.30 & 4.43 & 0.69 & 3.81 & 1.00 \\
\hline & & & \multicolumn{2}{|c|}{$F: 2.14$} & \multicolumn{2}{|c|}{$F: 0.41$} & \multicolumn{2}{|c|}{$F: 0.84$} & \multicolumn{2}{|c|}{$F: 0.09$} & \multicolumn{2}{|c|}{$F: 1.56$} \\
\hline & & & \multicolumn{2}{|c|}{ p: 0.096} & \multicolumn{2}{|c|}{ p: 0.748} & \multicolumn{2}{|c|}{ p: 0.472} & \multicolumn{2}{|c|}{ p: 0.966} & \multicolumn{2}{|c|}{ p: 0.200} \\
\hline
\end{tabular}

Source: Created by the authors using SPSS data analysis.

To compare the quality levels of the pedestrian areas, the scores given to the sub-criteria by the participants were evaluated. This evaluation was based on four quality criteria; however, the accessibility criterion was excluded from the evaluation at this stage. In addition, the expert group gave the sub-criteria a weight score of 10 for each main criterion. Quality scores were put forward by multiplying the mean score of the sub-criteria by their weight points. The maximum score for each criterion was 30, and all scores were converted into percentages (Table 4).

It has been observed that the activities criterion has the highest quality level in the study area (67.94\%). This is followed by the maintenance criterion (65.85\%), the safety criterion (64.09\%), and the design criterion (58.62\%). The reasons for the design criterion to have the lowest quality level are the insufficiency of vegetative elements, the presence of water elements and plastic elements in only a few streets, and the incapability of the structural elements to provide shade and protect the users from the negative effects of the sun. In general, users have stated that lighting is sufficient, but many streets have safety concerns.

The distribution of quality levels of all the surveyed streets is given in the diagram in Figure 8.

Bayındır Street has many cafés, bars, and restaurants. Apart from the possibility of seating provided by them, there is no seating equipment on the street. In parallel, as seen in the diagram in Figure 8 , the urban furniture sub-factor is given a low score by the users (2.04). At the same time, the users stated that the structural elements on this street are not well maintained (2.08). The best features of the area are floor coverings (4.50) and lightening (4.50).

It has been determined that this street is used more intensively in the morning and evening hours, and one of the sub-factors that has received the lowest score by the users is the security (1.96). As a result of the independent $t$-test, it was revealed that there are no statistically significant differences between women and men in terms of the lack of safety in the street $(p>0.05)$.

ACE, 15 (41.) CC BY-ND 3.0 ES | UPC Barcelona, España | Determination of Quality Criteria of Urban Pedestrian 14 Spaces. DOI: http://dx.doi.org/10.5821/ace.15.44.9297 
Table 4. Quality levels of the pedestrian area

\begin{tabular}{|c|c|c|c|}
\hline Criteria & WS & Mean & Score \\
\hline $\begin{array}{l}\text { Criteria 1: Design } \\
\text { Urban furniture } \\
\text { Floor coverings } \\
\text { Shops' usage style of pedestrian area } \\
\text { Green areas/Planting } \\
\text { Water elements (Ornamental ponds, fountains etc.) } \\
\text { Plastic elements (statue, monument, clock etc.) } \\
\text { Structural shading elements }\end{array}$ & $\begin{array}{r}1,88 \\
1,25 \\
1,50 \\
1,63 \\
1,13 \\
1,38 \\
1,25 \\
10,00\end{array}$ & $\begin{array}{l}1,82 \\
2,36 \\
1,70 \\
1,63 \\
1,51 \\
1,67 \\
1,62\end{array}$ & $\begin{array}{c}3,42 \\
2,95 \\
2,55 \\
2,65 \\
1,70 \\
2,30 \\
2,03 \\
17,59 \\
58,62 \%\end{array}$ \\
\hline $\begin{array}{l}\text { Criteria 2: Maintenance } \\
\text { Maintenance of structural elements } \\
\text { Maintenance of plants } \\
\text { Cleanliness }\end{array}$ & $\begin{array}{r}3,00 \\
3,00 \\
4,00 \\
10,00\end{array}$ & $\begin{array}{l}1,93 \\
1,91 \\
2,06\end{array}$ & $\begin{array}{c}5,79 \\
5,73 \\
8,24 \\
19,76 \\
65,85 \%\end{array}$ \\
\hline $\begin{array}{l}\text { Criteria 3: Activities } \\
\text { Social activities } \\
\text { Cultural activities }\end{array}$ & $\begin{array}{r}6,50 \\
3,50 \\
10,00\end{array}$ & $\begin{array}{l}2,05 \\
2,01\end{array}$ & $\begin{array}{c}13,35 \\
7,04 \\
20,38 \\
67,94 \%\end{array}$ \\
\hline $\begin{array}{l}\text { Criteria 4: Safety } \\
\text { Security (theft, petty crime etc.) } \\
\text { Lightening } \\
\text { To be sheltered from the weather conditions }\end{array}$ & $\begin{array}{r}4,00 \\
3,38 \\
2,63 \\
10,00\end{array}$ & $\begin{array}{l}1,71 \\
2,25 \\
1,82\end{array}$ & $\begin{array}{c}6,86 \\
7,59 \\
4,78 \\
19,23 \\
64,09 \%\end{array}$ \\
\hline
\end{tabular}

Source: Created by the authors using SPSS data analysis.

Inkılap Street has several cafés, restaurants, and shops. Also, the Çankaya Municipality building is located on this street. The street is heavily used all day long, mostly for passageway and business purposes. It is observed that there are a few occasional trees on the street. Green areas/planting (3.13) and structural shading elements (1.75) sub-criteria are observed to have low scores. Users reported that they found this street moderately safe (4.13).

izmir Street is one of the most commonly used pedestrian areas in the Kızlay region, with its cafés, restaurants, and several kinds of shops and offices. It boasts seating areas, ornamental pools, and vegetative elements. Pedestrians stated that they used this area mostly for business, shopping, transition, eating, and meeting purposes. The street is also used extensively throughout the day. There is a security point in the area, and the lighting sub-criterion also had a high score from the users (5.38).

Karanfil Street has one of the most used meeting points of Kızılay. There are many cafés, restaurants, shops, and offices on the street. Except for the meeting point, the participants use this place all day long for transition, work, shopping, walking, and socio-cultural activities. Seating units are located on the street. However, it is seen that the shops display their goods on the street locally. The fact that the participants scored low on the shops' usage style of pedestrian area sub-criterion (2.00) is an indication that they are uncomfortable with this. The safety score given to the street by the participants is also low (2.97). Independent t-test showed that there was a significant difference between women and men in terms of security $(p<0.05)$. Accordingly, men (2.53) find Karanfil Street more insecure than women (3.58).

ACE, 15 (41.) CC BY-ND 3.0 ES | UPC Barcelona, España | Determination of Quality Criteria of Urban Pedestrian 15 Spaces. DOI: $\underline{\text { htp://dx.doi.org/10.5821/ace.15.44.9297 }}$ 


\section{ACE Architecture, City and Environment}

Figure 8. Quality level diagrams of each street in the study area

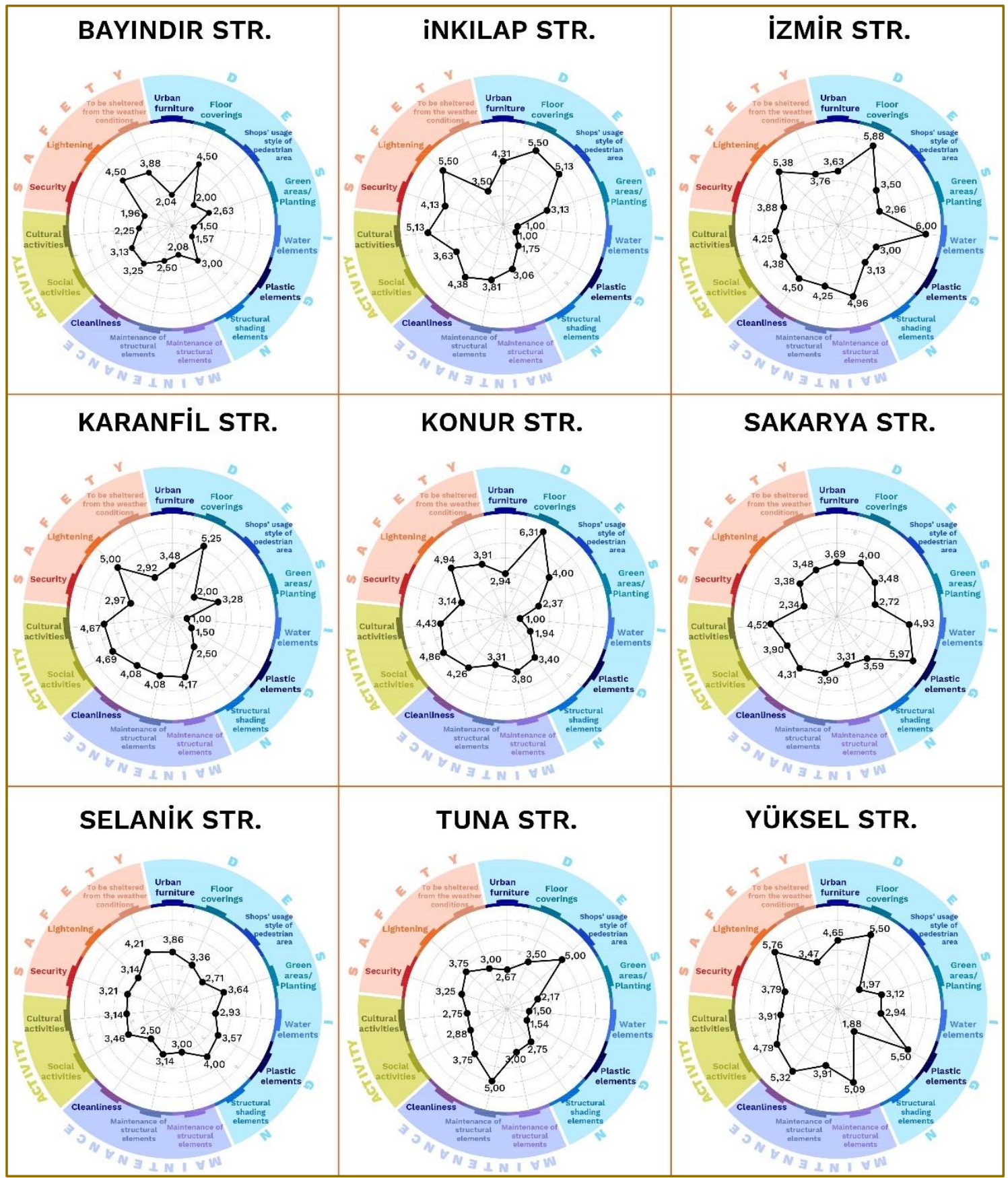

Source: Created by the authors.

Konur Street is one of the most crowded pedestrian streets in the Kızılay region. This place is mostly used for business, eating, and socio-cultural activities and as a passageway. Trees are rarely found on the street. The sitting areas of cafés and restaurants are covered with structural elements that can provide shade and protect against adverse weather conditions. There are no seating units on the street. This is one of the reasons that the urban furniture sub-criterion scored low (2.94). 
Sakarya Street has various shops, offices, and restaurants. Çankaya Municipality building is also located on this street. It is one of the most used pedestrian streets and is mostly used for business, passageway, meeting point, and socio-cultural activity purposes. Artistic events such as exhibitions and music concerts are occasionally held in this street. In parallel, the highest sub-criterion of the street was determined as plastic elements (5.97). This street was not found safe by the participants, and the lowest score among the sub-criteria was the security factor (2.34). As a result of the independent t-test, no statistically significant difference was found between men and women in terms of the security sub-criterion ( $p>0.05$ ).

Selanik Street is one of the streets that intersect with Sakarya Street. There is a flower market in one part of the street, and many shops, offices, and restaurants are located in the other part. The street is mostly used for shopping, business, and eating purposes. Referring to the diagram in Figure 8, it is noteworthy that the participants are not satisfied with certain factors like cleanliness (2.50), shops' usage style of pedestrian area (2.71), water elements (2.93), and maintenance of structural elements (3.00). The reasons for this are haphazard and ill-organized structural elements, insufficient maintenance, and obstruction of pedestrian circulation by shops overflowing on the street.

Tuna Street is one of the pedestrian streets used mostly for a transition. The number of shops is lower than on other streets. Apart from being a transition area, this street is used for walking, shopping, and eating purposes. Despite the appropriate width, urban furniture such as ornamental pools, plastic elements, and seating units are not sufficiently provided.

Yüksel Street is one of the most crowded pedestrian streets in the Kızlay region and is used extensively for transit and shopping. There are seating units and plastic elements in one part of the area. However, many cafés and some shops overflow the street, narrowing the area reserved for pedestrians and preventing circulation, which are significant concerns. Therefore, the shops' usage style of the pedestrian area sub-criterion is one of the factors with the lowest score from the participants (1.97).

\section{Discussion}

People use pedestrian zones not just as a transition space but as areas where they spend time away from traffic chaos and meet many of their needs, such as socializing, shopping, and participating in various activities. This study was carried out to determine the quality criteria for pedestrian zones. It focused on Kızılay, Ankara, as the research area. The physical characteristics of all the streets in the research area and their positive and negative aspects, according to the user groups, are discussed and analyzed. As Cengiz and Keçecioğlu Dağlı (2017), Ewing et al. (2016) and Isaacs (2000) stated, user experiences are an important factor to be considered in terms of the most effective and sustainable use of public open and green spaces.

The current research, which aims at determining the quality criteria for pedestrian spaces, presents five quality standards: design, maintenance, activities, accessibility, and safety. Through correct planning approaches, appropriate design, and various activities, pedestrian spaces contribute significantly to living quality, livability, and sustainability of urban centers. The primary purpose of these areas must be to provide the users with safe and livable spaces where they can access urban activities and move around comfortably. The quality criteria of the research, namely, design, maintenance, accessibility, activities, and safety, are consistent with the results of many pieces of research, such as that of Alves and Ramalho (2011), Bates (2013), Çol (2004), Madden and Schwartz (2005) and Project for Public Spaces (2013).

ACE, 15 (41.) CC BY-ND 3.0 ES | UPC Barcelona, España | Determination of Quality Criteria of Urban Pedestrian 
One of the most important functions of pedestrian spaces is their positive contribution to transportation. mentioned that pedestrian spaces should be integrated with the transportation system. The fact that the convenience of the access criterion, which is a sub-criterion of accessibility, has the highest score supports this statement.

Alves and Ramalho (2011) stated that pedestrian zones should be functional and be able to meet user needs. It has been determined that users can meet their needs, such as shopping, socializing, eating, and drinking at any time of the day in the region identified as the research area. However, the research area includes educational institutions and workplaces. Therefore, in addition to the 28-42 age group, the highest user density is in the 18-27 age group.

As a result of the analysis carried out with expert groups, it was determined that the criterion that most affected the quality level in the research area was activities. Most of the streets allow social activities, and some of them also allow cultural activities. It is thought that giving more space to cultural activities, in particular, will make the streets more usable.

With the analysis made, it was seen that the other criteria that affect the quality level of the pedestrian space are maintenance, safety, and design. The fact that maintenance includes the cleanliness sub-criterion has made it one of the most effective criteria. Although there is no difference between men and women in determining the quality criteria, the area's safety will enable the pedestrian space to be used more comfortably and intensively by women and young age groups. The design criterion, which is another high-rated factor, includes urban furniture, floor coverings, green areas/planting, water elements, plastic elements, and structural elements. These are particular features that affect pedestrian comfort and are reasons for users to choose this area.

\section{Conclusion}

Urban pedestrian spaces are the most used areas of city centers for various purposes and are part of urban life. They are also an effective tool for providing training on culture transfer to future generations; they also improve their face-to-face communication skills (Jou, 2011). Pedestrian spaces must fulfill economic, social, and environmental functions and be sustainable to meet people's comfort, relaxation, and interaction needs (Maliene \& Diciunaite-Rauktiene, 2015). In the streets, which are among the important public spaces of the city centers, the movement of vehicles, such as private vehicles, public vehicles, taxies, service vehicles, and other modes of transportation, takes place simultaneously with the pedestrian movement. It is often difficult to balance the needs of all these users. Not every public space has the capacity to satisfy all users. Unlike other users, pedestrians interact more with the place because they move more slowly, and they live close to the place. In city centers that have car-free networks, satisfying pedestrians is more advantageous than in other multiuser spaces. In the current literature, studies in which user experiences for pedestrian spaces are analyzed by quantitative techniques are rare. Most of them are carried out in public spaces in general. The concept of public space is general and inclusive. However, pedestrian areas have their own characteristics. For example, they are commonly created by pedestrianization of areas such as streets, squares, malls, and plazas. This research focuses on a pedestrian-only area located in the most central location of a capital that hosts people from all over the city and provides relevant data to the related literature.

Comments on the first question of the research (What are the pedestrian space quality criteria based on user experiences?): The research presents five quality standards: design, maintenance, activities, accessibility, and safety. These criteria are determined based on the pedestrians' opinions and, therefore, must be given utmost importance to meet their expectations. They are important

ACE, 15 (44.) CC BY-ND 3.0 ES | UPC Barcelona, España | Determination of Quality Criteria of Urban Pedestrian 18 Spaces. DOI: http://dx.doi.org/10.5821/ace.15.44.9297 
milestones that must be taken into account in pedestrianization efforts and in the management and development of existing pedestrian spaces. They can directly influence and shape the planning and design principles for pedestrian spaces. Well-designed pedestrian spaces are the indicators of both; urban quality of life, and urban centers' appeal. Through correct planning approaches, appropriate design, and implementation activities, pedestrian spaces contribute significantly to living quality, livability, and sustainability of urban centers.

Comments on the second question of the research (To what extent do public space quality criteria match those of the pedestrian space?): Some studies on determining the quality criteria of public spaces in general are Madden and Schwartz (2005): accessibility, comfort, sociability, and activities; Day et al. (2006): accessibility and safety; Alves and Ramalho (2011): security, density, activities-uses, accessibility, and comfort; Çalışkan (2011): safety, comfort, and pleasurability; Bates (2013): accessibility, use, design, and comfort; Project for Public Spaces (2013): accessibility, activities, comfort, and sociability; Mehta (2014): inclusiveness, meaningful activities, safety, comfort, and pleasurability; Alpak et al. (2018): inclusiveness, meaningful activities, comfort, safety, and pleasurability. To answer the research question, public and pedestrian space quality criteria are indeed similar, but achieving higher quality results in pedestrian spaces is much easier and more meaningful and sustainable.

Comments on the third question of the research (Does the factor analysis method work to determine the quality criteria that pedestrian spaces should have in order to satisfy users?): The factor analysis method, which is a quantitative technique, is a reliable, easy, and adaptable technique. The five factors obtained match many pieces of research that have different methods. It is observed that similar principles are taken as a basis in the studies that specifically deal with pedestrian areas. Some of them are Isaacs (2000): clarity, design, and pleasurability; Çol (2004): safety, accessibility, comfort, design, and landscaping; Day et al. (2006) and Pikora et al. (2006): plants, cleanliness, maintenance, design, and amenities; Alves and Ramalho (2011): security, density, activities-uses, accessibility, and comfort; Cengiz (2011): the purpose of use, crowdedness, image-noise-air pollution, safety, and expectations related to activity-plant-plastic art item; Çalışkan (2011): accessibility, use-activities, comfort, and sociability-interaction; Blaga (2013) and Ewing et al. (2016): comfort and safety; Aytaş and Uzun (2015): naturalness, manageability, and historicity; Cengiz and Keçecioğlu Dağlı (2017): pedestrian priority, social activities, and communication; Özkaynak and Korkmaz (2019): design, accessibility, landscape, and facades and building materials.

Comments on the fourth question of the research (In terms of quality criteria, at what level are Ankara's oldest and most used pedestrian areas?): As can be seen from the diagrams given in the findings section, unfortunately, the pedestrian streets under examination have a level just above the middle. The ones with the highest quality level are Izmir and Yüksel streets, and the street with the lowest quality level is Bayındır Street. Compared with the other streets, Selanik Street obtained consistent values; that is, the levels of quality factors were closest to each other.

The most important way to increase street scores is to design user-friendly pedestrian spaces. In this context, activities, safety, and design, which are among the criteria that most affect the quality level, come to the fore. However, the most common problems seen in the entire research area are that the components that add aesthetic value, such as water and plastic elements, are not sufficient, and the area is not found safe by the users. Therefore, depending on the width of the street, ornamental pools, sculptures, or monumental elements should be included. The presence of these, together with plant parterres and sitting units, will add aesthetic and functional value to the area. Likewise, the presence of security units at certain points of the area that are used extensively is a factor that will directly affect the use of these areas.

ACE, 15 (41.) CC BY-ND 3.0 ES | UPC Barcelona, España | Determination of Quality Criteria of Urban Pedestrian 19 Spaces. DOI: http://dx.doi.org/10.5821/ace.15.44.9297 
The results of the study and the quality criteria it sets can be used by planners, designers, managers, and policymakers for the following processes: to improve existing spaces, to create new ones, to measure the quality of urban spaces and to determine their dimensions, to take temporary actions before permanent interventions, to collect experience of users, and to promote future projections and strategies. In particular, knowing the relevant variables and user expectations will help planners and designers to plan and design in the process of creating quality spaces. Researchers will be able to adapt the method and criterion set to different case studies in evaluating public spaces. Pedestrians, civil society organizations, opinion leaders, community agencies, and so forth will be able to analyze the space they live in and make appropriate demands for its improvement.

\section{Authors' contribution}

Both authors contributed to all parts of the research. The first author mainly conceptualized the research, developed the literature section and made pictures, tables and other edits of article. The second author mainly created and analyzed the data. Other parts were completed by discussing and working together by two researchers.

Conflict of Interest: The authors declare no conflict of interests.

\section{Bibliography}

Açık Etike, B., \& Erdönmez Dinçer, E. (2019). Beşiktaş Meydanı ile San Marco Meydanının Kamusal Mekan Kalitelerinin Karşılaştırmalı Analizi. In L. G. Kaya (Ed.), Mimarlık, Planlama ve Tasarım Alanında Yeni Ufuklar (1 ed., pp. 11-34): Gece Akademi. Retrieved from https://scholar.google.com/scholar?hl=tr\&as sdt=0\%2C5\&q=Be\%C5\%9Fikta\%C5\%9F+Meydan\%C4\%B 1+ile+San+Marco+Meydan\%C4\%B1n\%C4\%B1n+Kamusal+Mekan+Kalitelerinin+Kar\%C5\%9F\%C4\%B1la\% C5\%9Ft\%C4\%B1rmal\%C4\%B1+Analizi\&btnG=

Alpak, E.M.; Düzenli, T., \& Yılmaz, S. (2018). Kamusal Açık Mekânların Kalitesi ve Sosyal Etkileşim Üzerindeki Etkileri/Quality of Public Open Space and Effects on Social Interaction. Journal of History Culture and Art Research, 7(2), 624-638.

Alves, F. M. B., \& Ramalho, A. M. L. (2011). Principles for the implementation of a pedestrian plan in medium size cities. Review of Urban \& Regional Development Studies, 23(1), 21-47. DOI: https://doi.org/10.1111/j.1467-940X.2011.00176.x

Architecture and Design Scotland. (2020). Place Standard tool, Strategic Plan 2020-2023. Retrieved from https://placestandard.scot/docs/Place Standard Strategic Plan.pdf

Asadi-Shekari, Z., Moeinaddini, M., \& Zaly Shah, M. (2014). A pedestrian level of service method for evaluating and promoting walking facilities on campus streets. Land Use Policy, 38, 175-193. DOI: https://doi.org/10.1016/j.landusepol.2013.11.007

Asadi-Shekari, Z., Moeinaddini, M., \& Zaly Shah, M. (2015a). A bicycle safety index for evaluating urban street facilities. Traffic injury prevention, 16(3), 283-288. DOI: https://doi.org/10.1080/15389588.2014.936010

Asadi-Shekari, Z., Moeinaddini, M., \& Zaly Shah, M. (2015b). Pedestrian safety index for evaluating street facilities in urban areas. Safety science, 74, 1-14. DOI: https://doi.org/10.1016/j.ssci.2014.11.014

Aytaş, i.., \& Uzun, S. (2015). Düzce kent merkezindeki yaya alanlarının görsel peyzaj kalitesinin belirlenmesi. istanbul Üniversitesi Orman Fakültesi Dergisi, 65(1), 11-29. Retrieved from https://forestist.org/Content/files/sayilar/75/70.pdf

ACE, 15 (44.) CC BY-ND 3.0 ES | UPC Barcelona, España | Determination of Quality Criteria of Urban Pedestrian 20 Spaces. DOI: $\underline{\text { htp://dx.doi.org/10.5821/ace.15.44.9297 }}$ 
Bates, K. (2013). Making pedestrian malls work: Key elements of successful pedestrian malls in the US and Europe. (PhD Thesis). University of Oregon, USA, Retrieved from https://scholar.google.com/scholar?hl=tr\&as sdt=0\%2C5\&q=Making+pedestrian+malls+work\%3A+Ke $y+$ +elements+of+successful+pedestrian+malls+in+the+US+and+Europe\&btnG $=$

Bayraktar, A., Aslanboğa, i., Özkan, B., Güney, A., \& Türkyılmaz, B. (1987). Izmir kenti içinde halkın açık alan gereksinimini karşılamak amacı ile bazı yol ve meydanların taşıt trafiğinden arındırılması olanakları üzerinde araştırmalar. Ege Üniversitesi Araştırma Fonu 063 Nolu Proje Raporu

Birişçi Yıldırım, T., Özel, A. E., \& Oktay, P. (2014). Yaya bölgeleri planlama ve tasarımı: Çanakkale Çarşı caddesi yaya yolu örneğinde. Retrieved from http://www.trafik.gov.tr/SiteAssets/Yayinlar/Bildiriler/pdf/C2-75.pdf

Bishop, P., \& Williams, L. (2012). The temporary city. Routledge London.

Blaga, O. E. (2013). Pedestrian zones as important urban strategies in redeveloping the community Case study: Alba Iulia Borough Park. Transylvanian Review of Administrative Sciences, 5-22. Retrieved from https://rtsa.ro/tras/index.php/tras/article/view/84/80

Bratuškins, U., \& Treija, S. (2017). Urban Communication: The Uses of Public Space in Riga Historical City Centre. Architecture and Urban Planning, 13(1), 100-105. DOI: https://doi.org/10.1515/aup-2017-0014

Cattell, V., Dines, N., Gesler, W., \& Curtis, S. (2008). Mingling, observing, and lingering: Everyday public spaces and their implications for well-being and social relations. Health \& place, 14(3), 544-561. DOI: https://doi.org/10.1016/j.healthplace.2007.10.007

Cengiz, C. (2011). Bartın Hükümet Caddesi Yaya Bölgesi Tasarımının İrdelenmesi. Bartın Orman Fakültesi Dergisi, 13(20), 80-79. Retrieved from https://dergipark.org.tr/en/pub/barofd/issue/3394/46760

Cengiz, C., \& Keçecioğlu Dağıı, P. (2017). Bartın Geleneksel Kent Dokusunda Yaya Konfor Düzeyinin Saptanmasına Yönelik Bir Çalışma. Bartın Orman Fakültesi Dergisi, 19(1), 19-31. Retrieved from https://dergipark.org.tr/en/pub/barofd/issue/27137/293022

Chiesura, A. (2004). The role of urban parks for the sustainable city. Landscape and urban planning, 68(1), 129-138. DOI: https://doi.org/10.1016/j.landurbplan.2003.08.003

Cohen, D. A., Inagami, S., \& Finch, B. (2008). The built environment and collective efficacy. Health \& place, 14(2), 198-208. DOI: https://doi.org/10.1016/j.healthplace.2007.06.001

Çalışkan, M. (2011). Kamu yararı bağlamında kamusal mekanlarda bir yayalaştırma örneği: Eminönü tarihi yarımada (Hobyar mahallesi ve çevresi) yayalaştırma projesi. (M.S. Thesis). Istanbul University, Graduate School of Natural and Applied Science, istanbul. Retrieved from https://polen.itu.edu.tr/handle/11527/2331

Çol, D. (2004). Kentsel ulaştırmada yaya alanları, istanbul avcılar-marmara caddesi yayalaştırma projesinin incelenmesi. (M.S. Thesis). Istanbul Technical University, Graduate School of Natural and Applied Science, İstanbul. Retrieved from https://polen.itu.edu.tr/handle/11527/11729

Das, D. (2008). Urban quality of life: A case study of Guwahati. Social Indicators Research, 88(2), 297310. Retrieved from https://link.springer.com/article/10.1007/s11205-007-9191-6

Day, K., Boarnet, M., Alfonzo, M., \& Forsyth, A. (2006). The Irvine-Minnesota inventory to measure built environments: development. American journal of preventive medicine, 30(2), 144-152.

Dowling, R., Reinke, D., Flannery, A., Ryus, P., Vandehey, M., Petritsch, T., . . . Bonneson, J. (2008). Multimodal Level of Service Analysis for Urban Streets-NCHRP Report 616. Retrieved from https://nacto.org/docs/usdg/nchrp rpt 616 dowling.pdf 
Ewing, R., Hajrasouliha, A., Neckerman, K. M., Purciel-Hill, M., \& Greene, W. (2016). Streetscape features related to pedestrian activity. Journal of Planning Education and Research, 36(1), 5-15.

Florida Department of Transportation. (2009). Quality/Level of Service. Retrieved from http://www.fltod.com/research/fdot/quality level of service handbook.pdf

Fruin, J. (1971). Pedestrian Planning and Design. Metropolitan Association of Urban Design and Environmental Planners., New York, 20.

Gehl, J. (2011). Life between buildings: Using public space. Washington: Island press.

Hajmirsadeghi, R. S., Shamsuddin, S., Lamit, H. B., \& Foroughi, A. (2013). Design's factors influencing social interaction in public squares. European Online Journal of Natural and Social Sciences, 2(4), 556. Retrieved from http://european-science.com/eojnss/article/view/264

Hansmann, R., Hug, S.-M., \& Seeland, K. (2007). Restoration and stress relief through physical activities in forests and parks. Urban forestry \& urban greening, 6(4), 213-225. DOI: https://doi.org/10.1016/j.ufug.2007.08.004

Hazır, G. (2019). Tarihi çevrelerde kentsel mekansal koridorların irdelenmesi üzerine bir araştırma: Ankara-Hamamönü örneği. (M.S. Thesis). Bartın University, Graduate School of Natural and Applied Science, Retrieved from https://acikerisim.bartin.edu.tr/handle/11772/2000

Iranmanesh, N. (2008). Pedestrianisation a great necessity in urban designing to create a sustainable city in developing countries. Paper presented at the 44th ISOCARP Congress. Retrieved from http://www.isocarp.net/Data/case studies/1130.pdf

Isaacs, R. (2000). The urban picturesque: an aesthetic experience of urban pedestrian places. Journal of Urban Design, 5(2), 145-180. DOI: https://doi.org/10.1080/713683961

Jacobs, A. B. (1993). Great streets. ACCESS Magazine, 1(3), 23-27. Retrieved from https://escholarship.org/uc/item/3t62h1fv

Jou, K. K. (2011). Pedestrian areas and sustainable development. World Academy of Science, Engineering and Technology, International Journal of Architectural and Environmental Engineering, 5(5), 228-235. Retrieved from https://www.semanticscholar.org/paper/Pedestrian-Areas-andSustainable-Development-Jou/dafc879d12d37ca4b8933a0bc9b456d91ba71e13?p2df

Kaplan, H., \& Acuner, A. (2005). Ankara'da yayalaştırma sorunsalı: Yaya alanlarının yasal çerçeve ve yerel yönetimlerin rolü kapsamında değerlendirilmesi. [Problematic in Ankara pedestrian: Evaluation of pedestrian areas in legal framework and scope of role of local governments]. Planlama Dergisi 2005(4), 112-123. Retrieved from https://www.researchgate.net/profile/Huelague Kaplan/publication/290390533 Ankara'da Yayalastir ma Sorunsali Yaya Alanlarinin Yasal Cerceve ve Yerel Yonetimlerin Rolu Kapsaminda Degerlendir ilmesi Pedestrianisation Problematique in Ankara the Role of Local Authority/links/56965db408a ec79ee329edd6.pdf

Khisty, C. J. (1994). Evaluation of pedestrian facilities: Beyond the level-of-service concept. Retrieved from https://www.worldcat.org/title/research-issues-on-bicycling-pedestrians-and-olderdrivers/oclc/636778892

Kızıloğlu, S., \& Polat, S. (2020). Sağlıklı Kentler için Kamusal Mekanlarda Katılımcı Tasarım Yaklaşımları: Bursa Altıparmak Meydanı ve Stadyum Caddesi Örneği. Paradoks: The Journal of Economics, Sociology \& Politics, 16(1). Retrieved from https://dergipark.org.tr/en/pub/paradoks/issue/53648/565058

Korça, P., \& Türkoğlu, H. (1991). Sehir merkezinde şehirsel tasarım: Kuzey Amerika deneyimi. Paper presented at the 1. Kentsel Tasarım ve Uygulamaları Sempozyumu, istanbul.

Kuntay, O. (1994). Yaya mekanı. Ankara: ilke Press.

ACE, 15 (41.) CC BY-ND 3.0 ES | UPC Barcelona, España | Determination of Quality Criteria of Urban Pedestrian 
Lydon, M., \& Garcia, A. (2015). Tactical Urbanism, Short-term Action for Long-term Change. Washington: IslandPress.

Madden, K., \& Schwartz, A. (2005). How to turn a place around: a handbook for creating successful public spaces: Project for Public Spaces, Incorporated.

Maliene, V., \& Diciunaite-Rauktiene, R. (2015). Factors Influencing Cities Pedestrian Street Functionality and Sustainable Land Use. Paper presented at the Proceedings of the 7th International Scientific Conference Rural Development 2015. Retrieved from http://researchonline.ljmu.ac.uk/id/eprint/4689/

Mehan, A. (2016). Investigating the role of historical public squares on promotion of citizens' quality of life. Procedia engineering, 161, 1768-1773. DOI: https://doi.org/10.1016/j.proeng.2016.08.774

Mehta, V. (2007). Lively streets: Determining environmental characteristics to support social behavior. Journal of Planning Education and Research, 27(2), 165-187. DOI: https://doi.org/10.1177/0739456X07307947

Mehta, V. (2014). Evaluating public space. Journal of Urban Design, 19(1), 53-88. DOI: https://doi.org/10.1080/13574809.2013.854698

Mehta, V., \& Bosson, J. K. (2018). Revisiting lively streets: Social interactions in public space. Journal of Planning Education and Research, 2018(1), 1-13. DOI: https://doi.org/10.1177/0739456X18781453

Miller, J. S., Bigelow, J. A., \& Garber, N. J. (2000). Calibrating pedestrian level-of-service metrics with 3-D visualization. Transportation Research Record, 1705(1), 9-15. DOI: https://doi.org/10.3141/1705-02

Moeinaddini, M., Asadi-Shekari, Z., Ismail, C. R., \& Zaly Shah, M. (2013). A practical method for evaluating parking area level of service. Land Use Policy, 33, 1-10. DOI: https://doi.org/10.1016/j.landusepol.2012.11.014

Moeinaddini, M., Asadi-Shekari, Z., Sultan, Z., \& Zaly Shah, M. (2015). Analyzing the relationships between the number of deaths in road accidents and the work travel mode choice at the city level. Safety science, 72, 249-254. DOI: https://doi.org/10.1016/j.ssci.2014.09.015

Moeinaddini, M., Asadi-Shekari, Z., \& Zaly Shah, M. (2014a). Analysing the relationship between parkand-ride facilities and private motorised trips indicators. Arabian journal for science and engineering, 39(5), 3481-3488. DOI: https://doi.org/10.1007/s13369-014-0979-9

Moeinaddini, M., Asadi-Shekari, Z., \& Zaly Shah, M. (2014b). The relationship between urban street networks and the number of transport fatalities at the city level. Safety science, 62, 114-120. DOI: https://doi.org/10.1016/j.ssci.2013.08.015

Monheim, R. (2003). The role of pedestrian precincts in adapting city centres to new lifestyles. In R. Tolley (Ed.), Sustainable transport: planning for walking and cycling in urban environments. Cambridge: Woodhead Publishing.

Muraleetharan, T., Adachi, T., Hagiwara, T., \& Kagaya, S. (2005). Method to determine pedestrian levelof-service for crosswalks at urban intersections. Journal of the Eastern Asia Society for Transportation Studies, 6, 127-136. DOI: https://doi.org/10.11175/easts.6.127

Muraleetharan, T., Adachi, T., Hagiwara, T., Kagaya, S., \& Kawamura, S. (2004). Method to determine overall level-of-service of pedestrians on sidewalks and crosswalks based on total utility value. Paper presented at the TRB Annual meeting. DOI: https://doi.org/10.2208/journalip.22.685

Nasution, A. D., \& Zahrah, W. (2012). Public open space privatization and quality of life, case study Merdeka Square Medan. Procedia-Social and Behavioral Sciences, 36, 466-475. DOI: https://doi.org/10.1016/j.sbspro.2012.03.051

ACE, 15 (44.) CC BY-ND 3.0 ES | UPC Barcelona, España | Determination of Quality Criteria of Urban Pedestrian 
National Research Council. (2000). Highway Capacity Manual. Transportation Research Board, National

Research Council., Washington, DC. Retrieved from http://ndl.ethernet.edu.et/handle/123456789/44778

Öncü Yıldız, A. M. (2017). 20. Yüzyılda Ankara'nın Kentsel Yapısı ve Ulaşım Sistemindeki Gelişmeler. Ankara Araştırmaları Dergisi, 5(1), 108-122. Retrieved from https://ankaradergisi.org/jvi.aspx?pdir=jas\&plng=tur\&un=JAS-81994\&look4=

Özkaynak, M., \& Korkmaz, Z. (2019). Yayalaştırılan Alanlardaki Sorunların Konya-Zafer Meydanı Örneği Üzerinden Değerlendirilmesi. Online Journal of Art and Design, 74). Retrieved from http://www.adjournal.net/articles/74/7415.pdf

Pacione, M. (2003). Urban environmental quality and human wellbeing-a social geographical perspective. Landscape and urban planning, 65(1-2), 19-30. DOI: https://doi.org/10.1016/S01692046(02)00234-7

Pikora, T. J., Giles-Corti, B., Knuiman, M. W., Bull, F. C., Jamrozik, K., \& Donovan, R. J. (2006). Neighborhood environmental factors correlated with walking near home: using SPACES. Medicine and science in sports and exercise, 38(4), 708-714. DOI: 10.1249/01.mss.0000210189.64458.f3

Project for Public Spaces. (2008). A Guide to Neighborhood Placemaking in Chicago. Retrieved from https://cdad-online.org/wp-content/uploads/2017/02/placemaking guide.pdf

Project for Public Spaces. (2013). What makes a successful place? Retrieved from http://www.pps.org/reference/grplacefeat/

Resuloğlu, Ç. (2020). Yapı, Anlam ve Kimlik üzerinden Ankara, Tunalı Hilmi Caddesi'ni Yeniden Anlamak. Online Journal of Art and Design, 8(1). Retrieved from http://www.adjournal.net/articles/81/8114.pdf

Rossini, F. (2019). Temporary urban intervention in the vertical city: a place-making project to reactivate the public spaces in Hong Kong. Journal of Urban Design, 24(2), 305-323. DOI: https://doi.org/10.1080/13574809.2018.1507674

Sarkar, S. (2003). Qualitative evaluation of comfort needs in urban walkways in major activity centers. Transportation Quarterly, 574), 39-59. Retrieved from https://babel.hathitrust.org/cgi/pt?id=mdp.39015058773691; seq=597

Saylan, S., \& Erdönmez Dinçer, E. (2017). Kamusal Alanların Kullanımında Mekan Kalitesi; Eminönü Mercan Mahallesi. Journal of Urban Academy, 10(29/1). Retrieved from https://www.kentakademisi.com/wp-content/uploads/2017/03/1-Kent-Akademisi-Dergisi-Seda-

Saylan-E-Erdonmez-Dincer-Kamusal-Alanlar\%C4\%B1n-Kullan\%C4\%B1m\%C4\%B1nda-Mekan-KalitesiEmin\%C3\%B6n\%C3\%BC-Mercan-Yil-10-Sayi-29-1-2017.pdf

Sayyadi, G., \& Awasthi, A. (2012). AHP-based approach for location planning of pedestrian zones: Application in Montréal, Canada. Journal of Transportation Engineering, 139(2), 239-246. DOI: https://doi.org/10.1061/(ASCE)TE.1943-5436.0000493

Stauskis, G. (2018). Re-pedestrianising open spaces through optimising mobility in urban landscape: great importance of the small detail. Scientific journal of Latvia University of Life Sciences and Technologies, 13(13), 57-64. DOI: 10.22616/j.landarchart.2018.13.06

Surat, H., \& Yaman, Y. K. (2015). Kent İçi Yolların Yaya Kullanımına Yönelik Değerlendirilmesinde Kamu Tercihi. Kastamonu Üniversitesi Orman Fakültesi Dergisi, 15(1), 58-72. DOI: https://doi.org/10.17475/kuofd.34891

Şenkaynak, P. (2010). Yaya bölgelerinin kentsel peyzaj planlama açısından önemi ve istanbul'daki bazı örneklerin incelenmesi. (M.S. thesis). Istanbul University, Graduate School of Natural and Applied Science, Istanbul,

ACE, 15 (44.) CC BY-ND 3.0 ES | UPC Barcelona, España | Determination of Quality Criteria of Urban Pedestrian 24 Spaces. DOI: $\underline{\text { htp://dx.doi.org/10.5821/ace.15.44.9297 }}$ 
Tan, D., Wang, W., Lu, J., \& Bian, Y. (2007). Research on methods of assessing pedestrian level of service for sidewalk. Journal of Transportation Systems Engineering and Information Technology, 75), 74-79. DOI: https://doi.org/10.1016/S1570-6672(07)60041-5

Topçu, K. (2011). Alışveriş alanlarının mekânsal kalite açısından değerlendirilmesi: Karşılaştırmalı bir analiz. (PhD Thesis). Selçuk University, Graduate School of Natural and Applied Science, Retrieved from http://acikerisimarsiv.selcuk.edu.tr:8080/xmlui/handle/123456789/2090

Tudor-Locke, C., Bittman, M., Merom, D., \& Bauman, A. (2005). Patterns of walking for transport and exercise: a novel application of time use data. International journal of behavioral nutrition and physical activity, 2(1), 5. DOI: https://doi.org/10.1186/1479-5868-2-5

Uzgören, G., \& Erdönmez, M. E. (2017). Kamusal açık alanlarda mekan kalitesi ve kentsel mekan aktiviteleri ilişkisi üzerine karşılaştırmalı bir inceleme. Megaron, 12(1), 41-56. DOI: 10.5505/megaron.2016.42650

Weiss, S. J. (2007). Evasion of Temporality. Retrieved from https://src.lafargeholcimfoundation.org/dnl/b5dee3fc-e2e2-494d-a9e9-e7427108cc8c/F07-WK-Temp-weiss02.pdf

Yalçınkaya, F. (2007). Ankara-Bahçelievler Aşkabat Caddesi'nin (7. Cadde'nin) Yayalaştırılmasının Peyzaj Mimarlığı Açısından irdelenmesi. (M.S. Thesis). Ankara University, Graduate School of Natural and Applied Science, Ankara. Retrieved from https://dspace.ankara.edu.tr/xmlui/handle/20.500.12575/28898

Zafer, B. (1996). Yaya Bölgeleri Planlama Ilkeleri. İzmir: Ofset Atölyesi.

Zafer, B. (1998). Aydın Germencik Belediyesi yaya bölgesi tasarımı üzerine bir araştırma. Ekoloji Dergisi, 26, 27-30.

ACE, 15 (44.) CC BY-ND 3.0 ES | UPC Barcelona, España | Determination of Quality Criteria of Urban Pedestrian 